\title{
Innovations in agronomy for food legumes. A review
}

\author{
Kadambot H. M. Siddique • Chris Johansen • \\ Neil C. Turner • Marie-Hélène Jeuffroy • \\ Abul Hashem • Dogan Sakar • Yantai Gan • \\ Salem S. Alghamdi
}

Accepted: 8 October 2010 /Published online: 18 March 2011

(C) INRA and Springer Science+Business Media B.V. 2011

\begin{abstract}
Although there is increasing awareness of the importance of food legumes in human, animal and soil health, adoption of improved production technologies for food legume crops is not proceeding at the same pace as for cereal crops. Over the previous decade, the only food legumes to have shown significant production increases have been chickpea, lentil and faba bean in North America, chickpea in Australia, and faba bean in Europe. In
\end{abstract}

K. H. M. Siddique $(\square) \cdot$ N. C. Turner

The UWA Institute of Agriculture,

The University of Western Australia,

35 Stirling Highway,

Crawley, WA 6009, Australia

e-mail: kadambot.siddique@uwa.edu.au

K. H. M. Siddique - C. Johansen • N. C. Turner

Centre for Legumes in Mediterranean Agriculture,

Faculty of Natural and Agricultural Sciences,

The University of Western Australia,

35 Stirling Highway,

Crawley, WA 6009, Australia

M.-H. Jeuffroy

UMR Agronomie INRA/AgroParisTech,

BP 01, 78850 Thiverval-Grignon, France

\section{A. Hashem}

Department of Agriculture and Food WA, P.O. Box 483, Lot 12, York Road,

Northam, WA 6401, Australia

D. Sakar

Dicle University Faculty of Agriculture,

Diyarbakr, Turkey

Y. Gan

Agriculture and Agri-Food Canada,

Gate\#3, Airport Road E.,

Swift Current, SK S9H3X2, Canada

K. H. M. Siddique $\cdot$ S. S. Alghamdi College of Food and Agricultural Sciences, King Saud University, P.O. Box 2460, Riyadh 11451, Saudi Arabia smallholder farming in developing countries, production trends have mostly been static or have declined over the past decade despite the existence of technology that should permit higher and more stable yields. Ability to reverse negative trends is jeopardized by climate change as food legumes are mostly grown rainfed and are being exposed to increasingly variable and extreme weather. This review examines recent innovations in cultivation technology for the major food legumes - chickpea, lentil, dry pea, faba bean, lupin, common bean, mung bean, black gram, cowpea, and pigeonpea - and explores constraints to their adoption, particularly by resource-poor smallholder farmers. Conservation agriculture, involving minimum soil disturbance, maximum soil cover, and diverse rotations, has contributed to sustainable cropping system production in large-scale commercial farming systems in the Americas, Europe, Australia, and Turkey. Temperate food legumes have been incorporated into such systems. Adoption of conservation agriculture is only just beginning for smallholder farming in Asia and Africa, catalyzed by the development of low-cost implements suitable for minimum tillage. Water use efficiency improves with conservation agriculture as it allows for earlier planting, reduced soil evaporation, better weed management, and increased access to nutrients. Ecosystem-based approaches to plant nutrition are evolving which place more reliance on accessing organic and mineral reservoirs than in replenishing the immediately available pool with chemical fertilizers, leading to enhanced nutrient use efficiency of cropping systems. Ecosystem-based approaches are also being applied to management of weeds, diseases, and insect pests of food legumes, again with decreased reliance on synthetic chemicals. In achieving sustainable agricultural production systems, there is increasing realization of the need to move towards the tenets of organic agriculture, as exemplified in conservation agriculture and ecosystem-based approaches to plant nutrition and pest management. This does not 
necessarily imply a desire to qualify for organic product certification but more a realization of the need for sustainable agriculture. The movement towards conservation and organic agriculture encourages greater inclusion of food legumes, and legumes generally, in cropping systems. Unfortunately, however, technology transfer to resource-poor farming situations, where most food legumes are produced, remains a major bottleneck to meeting global demand. More participatory approaches to technology development, testing, and dissemination are required than hitherto practiced. It is suggested that this process could be enhanced by better focusing on major constraints within the value addition chain for food legumes.

Keywords Legume area trends . Climate change . Conservation agriculture $\cdot$ Smallholder farming $\cdot$ Water use efficiency · Nutrient use efficiency · Weeds · Integrated disease management $\cdot$ Integrated crop management

\section{Contents}

1. Introduction $\ldots \ldots \ldots \ldots \ldots \ldots \ldots \ldots \ldots \ldots \ldots \ldots \ldots$

2. Recent trends in area, yield and production. . . . . . 2

3. Coping with climate change ............ 4

4. Role of legumes in conservation agriculture ......5 5

5. Increasing water and nutrient use efficiency . . . . . 7

6. Weed, disease and pest management .......... 11

7. Integrated crop management .............. 13

8. Improved legume agronomy for resource-poor farmers . . . . . . . . . . . . . . . 15

9. Conclusion . . . . . . . . . . . . . . . . . . 16

10. References ..................... 17

\section{Introduction}

There is increasing awareness of the importance of food legumes in improving the health of humans (Tharanathan and Mahadevamma 2003), production of farm animals (Gatel 1994), the soil in which legumes grow (Biederbeck et al. 2005), and in mitigating greenhouse gases (Lemke et al. 2007). Nevertheless, food legumes remain poor cousins to the major cereal crops (rice, wheat, maize) due to the ever-increasing global demand for cereals from burgeoning human populations. Priorities for cultivation and research in food legumes remain secondary to those for cereals in most cropping systems. Contributing to this is the relatively greater sensitivity of food legumes to various abiotic and biotic stresses than cereals, increasing their cultivation risk, and their lower grain yield potential compared with competing cereal crops. While genetic improvement is required to address these problems, agronomic improvements can significantly contribute to closing the yield gap induced by various stresses. Practically, however, genetic and agronomic improvements should proceed in a complementary manner, as a new genotype often requires a change in cultivation practice to achieve potential yields. This paper examines some of the more recent, since the turn of the century, innovations in agronomic practices that are contributing to, or potentially can contribute to, increased yields and production of the major food legumes.

In this review, we address the following major food legumes: chickpea (Cicer arietinum L.), lentil (Lens culinaris Medicum), dry pea (Pisum sativum L.), faba bean (Vicia faba L.), lupin (Lupinus spp.), common bean (Phaseolus vulgaris L.), mung bean [Vigna radiata (L.) Wilczek], black gram [Vigna mungo (L.) Hepper], cowpea (Vigna unguiculata L.), and pigeonpea (Cajanus cajan L.). These crops are grown across a wide range of farming systems, from subsistence agriculture to sophisticated commercial production systems. We firstly examine to what extent any recent increases in yield and production of food legumes in major producing countries over the past decade can be attributed to implementation of improved agronomy. Concepts and practice of conservation agriculture, involving trends towards minimum tillage, have advanced considerably in recent years, and legumes are considered important components of such systems. Ever-increasing degradation of agricultural lands worldwide and climate change are demanding major changes in traditional agronomic practices. Of particular importance in this regard is the formulation of strategies to improve water and nutrient use efficiency. Rapidly changing incidence and manifestation of weed, disease, and pest problems require changes in traditional agronomic practices. There is increasing realization of the need to implement more ecologically based practices and at least move in the direction of organic agriculture, in which legumes have a major role. Farmer implementation of improved agronomic practices requires integration of many interacting components; there is a need for translation of findings from component-based research into integrated crop management packages. Finally, we examine reasons behind slow adoption of agronomic innovations by smallholder, resource-poor cultivators of food legumes and suggest means of hastening adoption.

\section{Recent trends in area, yield, and production}

Significant increases in area sown to food legumes in the recent decade have occurred mainly in countries where they are grown on a commercial scale on large land holdings, as in North America and Australia (FAO 2010; Fig. 1). There has been little change and sometimes a decline in area where smallholder subsistence agriculture predominates. This is despite increasing local and global demand for each of these commodities.

India is the major producer of chickpea, where there has been a gradual recovery in production area after a slump at 
Area (m ha)
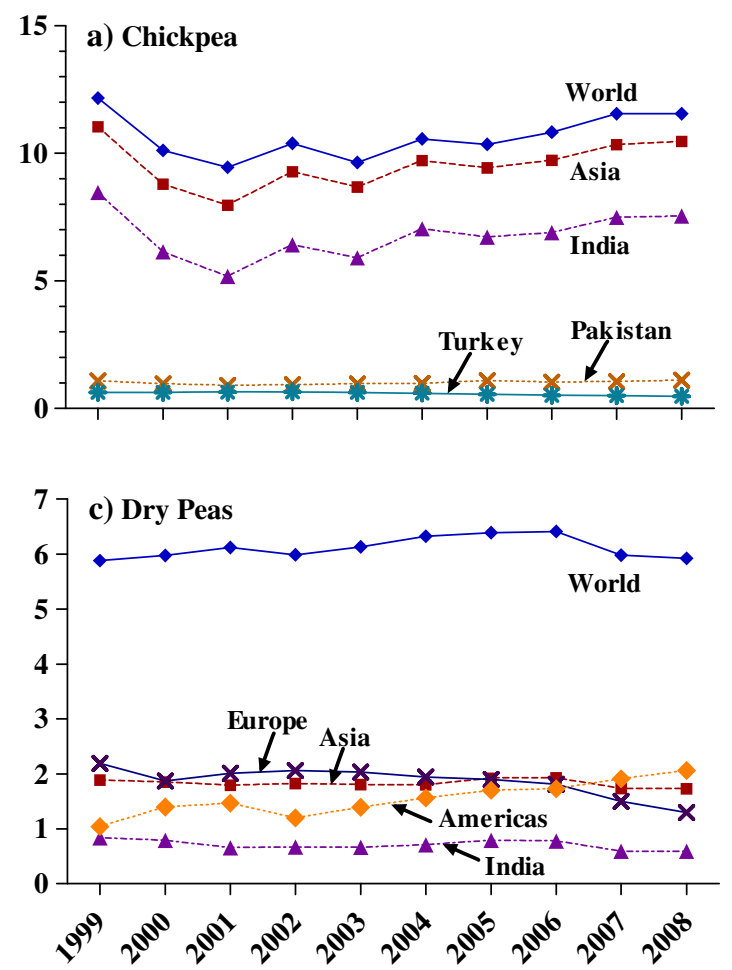

Area (m ha)
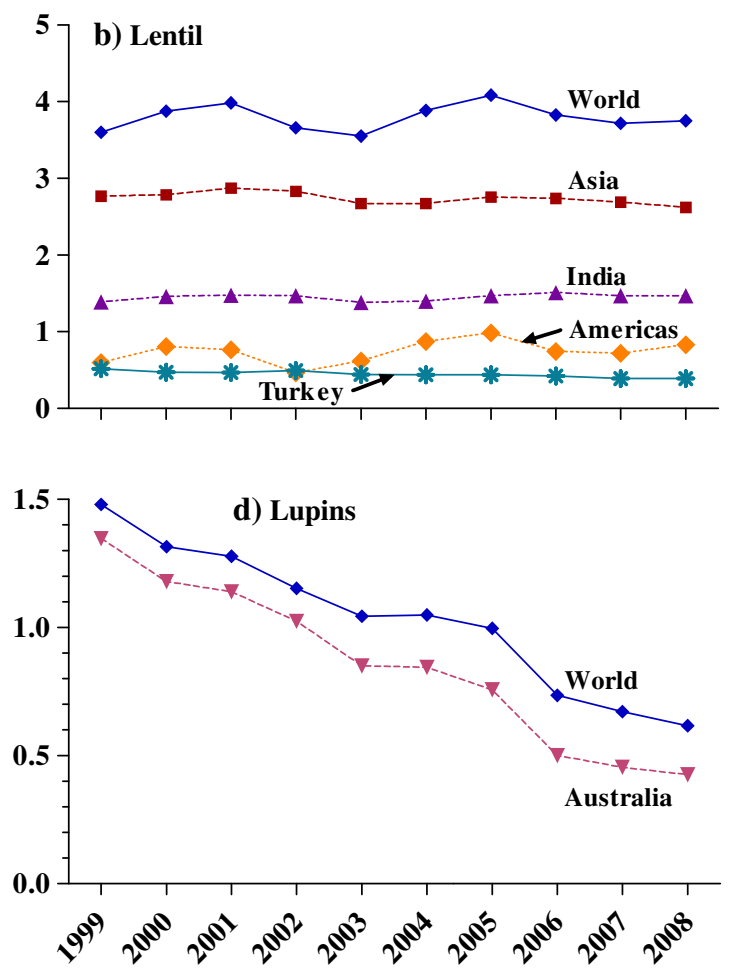

Fig. 1 Trends in areas sown to a chickpea, b lentil, $\mathbf{c}$ dry peas, and $\mathbf{d}$ lupins in major producing countries and regions in the previous decade. Values for "Asia" include those for India, Pakistan, and Turkey. Source: FAO (2010)

the beginning of the decade (Fig. 1a). This can be primarily attributed to the expansion of chickpea in Peninsular India with the adoption of short duration varieties (Satyanarayana et al. 2001). There has been a gradually declining trend in Turkey, the other major producer in Asia (Fig. 1a). The area planted to chickpea in North America and Australia declined from 2000 to 2005 (FAO 2010), mainly due to outbreaks of ascochyta blight. However, since then the area sown in these locations has recovered, due to better disease management via the introduction of varieties with enhanced host plant resistance (Chandirasekaran et al. 2009), and agronomic measures such as more effective fungicidal spraying (Armstrong-Cho et al. 2008) and plant canopy manipulation and management (Gan et al. 2006, 2009). As chickpea is predominantly a rainfed crop, there are no clear trends in yields (FAO 2010) which fluctuate from year to year according to seasonal rainfall.

The only appreciable increases in area sown to lentil over the past decade have been in North America (Fig. 1b), which has been largely driven by the increased incentives of adopting diversified cropping systems in the northern Great Plains (Gan et al. 2010). Areas sown to lentil have remained steady in India and Nepal, but have declined in Pakistan and Bangladesh (FAO 2010; Fig. 1b). There has also been a decreasing yield trend in Pakistan, but yields are increasing in Bangladesh mainly due to adoption of varieties with increased resistance to the major disease, stemphylium blight (Aw-Hassan et al. 2009). The area sown to lentil has declined in Turkey (Fig. 1b), but production has been compensated for by an increasing yield trend (FAO 2010). This can be attributed to the spread of certified seed of high yielding and early maturing lentil cultivars with good quality characteristics especially in the south-eastern region of Turkey.

The area of dry pea cultivation has increased only in North America, especially Saskatchewan, Canada (Fig. 1c). Rotations of the shallow-rooting dry pea (Liu et al. 2010) with cereals and oilseeds have improved resource use efficiency (Miller et al. 2003), increased yield and quality of subsequent crops (Gan et al. 2003), and enhanced biological attributes of the soil (Biederbeck et al. 2005). The area sown to faba bean has increased in both North America and Europe but declined in Asia (FAO 2010). There are no clear yield trends with either dry pea or faba bean (FAO 2010); there is considerable year-to-year variation in yield attributable to rainfall and foliar disease. Area and production of lupin in Australia, by far the major producer of lupin grain, has declined markedly over the past decade (Fig. 1d). This is mainly due to declining market demand and increasing herbicide tolerance of weeds in lupin crops in Australia (Sweetingham and Kingwell 2008). 
Globally, the area sown to beans has increased primarily due to increases in both Africa and Asia (FAO 2010). In Africa, increasing areas of common bean are being sown while areas under mung bean and black gram have increased in South and East Asia. These increases are attributed mainly to the availability of improved varieties, such as shorter duration and more disease-resistant mung bean (Shanmugasundaram 2006), rather than any improvements in agronomic management. Africa remains the major producer of cowpea, but there has been no appreciable increase in area sown or yield over the last decade (FAO 2010). In contrast, cowpea area and yields have increased in Asia, probably as a result of availability of improved varieties (Singh et al. 2002). India is the major producer of pigeonpea, but area and yields have remained relatively stable over the past decade (FAO 2010). Myanmar appears to be the only country where pigeonpea area and yields have increased. This has been mainly driven by the export market to neighboring India (Thaung and Choi 2008).

This brief overview of recent yield and production trends has found little evidence of agronomic improvements leading to upward trends. The only examples are chickpea, lentil, and faba bean in North America, chickpea in Australia, and faba bean in Europe, where a combination of genetic and agronomic improvement factors can be attributed to the increases. For grain legumes grown under smallholder, near-subsistence farming conditions, it is difficult to ascribe any specific agronomic improvement to significant and persistent increases in area sown or yield. Any increasing trends noted are mainly attributable to the availability of improved varieties or economic factors driving production. This is disappointing considering the quantum of agronomic research on food legumes undertaken for resource-constrained, smallholder conditions and the increasing demand for legume grain. This raises questions as to appropriate targeting of the research and whether the relevant information is indeed reaching farmers. This is discussed in more detail later in this review.

\section{Coping with climate change}

On-going climate change poses an increasing threat to production of target food legumes, requiring urgent implementation of agronomic and genetic means of addressing this threat. Predictions in the Fourth Assessment Report of the Intergovernmental Panel on Climate Change (Christensen et al. 2007) suggest that the warming trend observed throughout much of the world over the past four decades will continue through the twenty-first century, with extreme events becoming more frequent. In addition, rainfall will decrease in the mid-latitudes where most food legumes are grown; in tropical regions rainfall may increase, but this is likely to arise from extreme rainfall events and more frequent periods of within-season drought (Christensen et al. 2007). While specific temperature increases and frequency of extreme temperatures and droughts are locally variable, the general consensus is that crops and cropping systems should be more flexible and, except for regions of North America, northern Europe, and northern Asia where temperatures are below the optimum for crop growth, changes in climate are likely to decrease rather than increase yields. For example, Cooper et al. (2009) used a modeling approach to predict that a temperature rise of $3^{\circ} \mathrm{C}$ will reduce the current median yield of peanuts in Zimbabwe by 33\% and pigeonpea in Kenya by $19 \%$, largely as a result of shorter growing periods and earlier maturity at higher temperatures. The decrease in time to maturity results in water left in the profile such that adjusting the phenology of plants is suggested as one mechanism to manage climate change (Cooper et al. 2009; Vadez et al. 2011). Modeling a 10\% decrease in daily rainfall in groundnut reduced yields by less than 9\% (Cooper et al. 2009), much less than the decrease in median yield for a $3^{\circ} \mathrm{C}$ rise in temperature, but this does not take into account the predicted changes in rainfall distribution and crop failures.

While the Intergovernmental Panel on Climate Change (Christensen et al. 2007) predicted that extremes of high temperature and rainfall and the length of dry spells are likely to increase over the next 90 years, the panel was less able to predict the degree and extent of such extreme events. The ability of food legumes to adapt to the predicted extremes of temperature and rainfall is largely unknown. In a recent study, Prasad et al. (2006) showed that when air temperature increased from $36 / 26^{\circ} \mathrm{C}$ to $40 / 30^{\circ} \mathrm{C}$, panicle emergence in sorghum was delayed by more than 20 days, panicles were smaller and less branched, and seed set, seed size, and growth rate of seeds was markedly reduced. The reduced seed set resulted from poor pollen production and viability. The reductions were slightly greater when the carbon dioxide level was doubled from $350 \mu \mathrm{mol} \mathrm{mol}^{-1}$ to the predicted $700 \mu \mathrm{mol} \mathrm{mol}^{-1}$. A drastic reduction in seed set at high temperatures has also been observed in rice. Exposing rice to $34^{\circ} \mathrm{C}$ for $1 \mathrm{~h}$ at peak anthesis around $1100 \mathrm{~h}$ caused sterility (Jagadish et al. 2007), and exposing rice spikelets to $>35^{\circ} \mathrm{C}$ for 5 days at anthesis induced complete sterility (Satake and Yoshida 1978). As most legumes are indeterminate, the effect of a short period of supra-optimal temperatures is less certain and unlikely to be as drastic as in determinate cereals. However, among legumes, high temperatures around flowering decreased flower number and seed set in peanuts (Prasad et al. 2000, 2001, 2003; Kakani et al. 2002), kidney bean or common bean (Gross and Kigel 1994; Prasad et al. 2002), and 
cowpea (Hall 1992). In 21 peanut genotypes, the optimum temperature for pollen germination varied from $25.5^{\circ} \mathrm{C}$ to $35.0^{\circ} \mathrm{C}$ and for pollen tube growth from $30.5^{\circ} \mathrm{C}$ to $36.8^{\circ} \mathrm{C}$ (Kakani et al. 2002). Challinor et al. (2007) used a modeling approach to show that high temperatures reduced peanut yields in some locations in India.

Agronomic options for combating increasing temperatures and incidence of drought induced by climate change are planting density, the use of fertilizers, fallows and rotations, time of planting, and supplemental irrigation to increase yields. Decreasing planting density is a widely used procedure to mitigate the effects of low rainfall, particularly when the crop is grown on stored soil moisture. The influence of changing planting density was simulated in pigeonpea; increasing density counterbalanced yield reductions when temperatures increased by $3^{\circ} \mathrm{C}$, but only in years with high rainfall (Turner 2008). Moreover, doubling the planting density left the same amount of water in the profile at maturity, suggesting that changing the planting density did not change water use and therefore provides only limited scope to manage legume crops to overcome yield limitations induced by climate change. Cooper et al. (2009) also showed that increasing nutrient input in low input smallholder farming systems increased yields markedly and overcame any yield reductions in years with higher temperatures from climate change. While the model was based on fertilizer input, the use of mixed species legume fallows (Ndufa et al. 2009) to increase soil organic matter and nutrient status, and rotations to control weeds and diseases, would help overcome yield reductions from climate change. The increasing variability of rainfall suggests that water conservation measures will become increasingly important. Prevention of runoff, minimum tillage to reduce soil evaporation, micro-catchments to concentrate water in the root zone, early planting to reduce soil evaporation before crop emergence, weed control and, where available, use of strategically timed supplemental irrigation are all possible avenues for adapting to climate change and are further discussed below.

\section{Role of legumes in conservation agriculture}

Conservation agriculture is increasingly being practiced in many parts of the world, mainly in response to increased recognition of soil degradation and thus sustainability of agriculture. Conservation agriculture is defined as minimal soil disturbance and permanent soil cover combined with rotations (Hobbs et al. 2008). Derpsch (2005) estimated that, by $2005,95.5$ million ha would be farmed using principles of conservation agriculture, although not always simultaneously including all facets of the practice-minimum tillage, ground cover, and crop rotation. Ninety-six percent of conservation agriculture was practiced in the Americas and Australia, and $<2 \%$ in the major foodproducing zone of the Indo-Gangetic Plain (Derpsch 2005), where major soil degradation processes have long been documented (Abrol et al. 2000). Implementation of conservation agriculture has depended upon the development of appropriate no-till or minimum tillage implements and effective control of weeds, primarily through use of herbicides (Baker et al. 2006).

Major advantages of conservation agriculture are purported to be reduced wind and water erosion of topsoil, increased water use efficiency through improved water infiltration and retention, increased nutrient use efficiency through enhanced nutrient cycling and fertilizer placement adjacent to seed, reduced oscillation of surface soil temperatures, increased soil organic matter and diverse soil biology, reduced fuel, labor and overall crop establishment costs, and more timely operations (Hobbs et al. 2008). However, the supposed benefits of conservation agriculture are not universal and Giller et al. (2009) pointed out circumstances where it did not appear to be advantageous, particularly for smallholder, resource-poor farmers. Such farmers find it difficult to maintain a soil cover of crop residue or a cover crop due to the competing requirements for such biomass for fodder, fuel, or building material. Appropriate herbicides are usually not available to, or affordable by, resource-poor farmers, resulting in increased weeding costs and weed constraints if tillage is reduced under conservation agriculture. Minimum tillage/no-till implements have mostly been developed for large tractordrawn equipment in extensive agriculture and are therefore not available for smallholders reliant on draft power from animals or small machines (e.g., two-wheel power tillers). Nevertheless, conservation farming in southern Africa that incorporates basins to minimize runoff and greater water infiltration, mulching to reduce water loss by soil evaporation, timely planting on the first rains, application of manure to provide better soil structure, top dressing with fertilizer depending on rainfall, rotation with legumes, and timely weed control, have increased yields by up to $100 \%$ and increased profitability over conventional farming (Mazvimavi et al. 2008).

Legumes are ideal crops for two components of conservation agriculture - soil cover and rotation-either as a growing crop or as residue. The benefits of food legumes in cereal-based cropping systems have been discussed in detail by Siddique et al. (2008) and are summarized as follows. The major advantage of legumes is the addition of fixed nitrogen $(\mathrm{N})$ to the soil and nondepletion of existing soil $\mathrm{N}$ reserves because of their ability to meet their own $\mathrm{N}$ needs through fixation. Legumes contribute high quality organic matter to the soil because of their high $\mathrm{N}$ to carbon (C) ratio and are effective in 
breaking disease cycles of particular cereal crops because of their genetic dissimilarity with cereals and thus host different sets of pests and diseases. Many legumes are deep rooted, contributing to nutrient cycling and water infiltration in the soil. Further, some legumes access nutrients otherwise unavailable to other crops, by mechanisms such as dissolution by root exudates, and render those nutrients available to subsequent crops.

Soybean is a major component of conservation agriculture systems in the Americas, both contributing to and benefiting from conservation agriculture practices. For example, soybean is a major component of conservation agriculture systems in Brazil, where there has been widespread adoption of this practice over the previous three decades (Bolliger et al. 2006). There are Brazilian examples of conservation agriculture resulting in continuous soil cover (minimizing erosion), gradual increases in soil organic matter, integration of livestock, movement of surface-applied lime through the acid soil profile, breakage of compact soil layers, and reduced reliance on agrochemicals, all under a variety of climatic and edaphic conditions, farm sizes, and degree of mechanization (Bolliger et al. 2006). The current target food legumeslentil, chickpea, pea, and faba bean - are part of conservation agriculture systems in North America, Australia, and Turkey, but their performance in those systems has not been assessed to the extent of soybean. In Australia, some advantages of minimum tillage for pulses have been quantified for water-limited environments. In these environments, stubble retention in no-till systems $(<20 \%$ soil disturbance) significantly increases soil water storage (O'Leary and Conner 2007) and reduces soil compaction (Li et al. 2001) as compared with tilled soil. Combinations of wider row spacing (e.g., 30 vs. $20 \mathrm{~cm}$ ) and stubble retention are proving advantageous for chickpea and lentil by reducing herbicide damage and by the stubble acting as a trellis thereby improving harvestability and grain quality (Crowe and Brand 2010). Adjustment of row spacing to match soil water availability has been an important agronomic adaptation for maximizing pulses yield in conservation agriculture systems in Australia (Hawthorne 2010).

While the three components of conservation agricultureminimum tillage, soil cover, and rotation - have effectively been combined in some systems in the Americas and Australia, it has been difficult to combine all components in cropping systems including target legumes in developing agriculture. Despite the general spread of conservation agriculture in Brazil, smallholder farmers are usually able to only partially adopt the recommended technologies due to the complex socioeconomic circumstances and resource limitations they face (Bolliger et al. 2006). Introduction of conservation agriculture into smallholder agriculture con- ducted by resource-poor farmers should favor increased cultivation of target food legumes and hasten ingress of agronomic innovations that would increase their yield. First attempts to introduce conservation agriculture, and especially minimum tillage, in all locations where it was eventually widely adopted, met with initial skepticism from farmers, researchers, extension agents, and input suppliers (Derpsch 2002). This is also the case for traditional smallholder farming systems, but prospects for overcoming the overwhelming constraints to conservation agriculture introduction in those circumstances are now becoming apparent.

A first step is the introduction of minimum or zero tillage (also called conservation tillage) in agriculture where full tillage, usually with animal traction, has been a tradition. Lack of access to minimum tillage implements developed for large-scale agriculture is considered a major constraint. However, in developing countries where fourwheeled tractors are used, simplified, low-cost versions of minimum tillage have been developed and adopted. An example is in the Indo-Gangetic Plain of India and Pakistan where the area sown to no-till wheat has increased from 12,800 ha in 1999-2000 to 2.4 million ha in 2005-2006 (Hobbs et al. 2008). This increase did not rely on imported equipment from areas already practicing conservation agriculture but, based on concepts used in those areas, local development and commercial manufacture of implements best suited to prevailing tractor types, soil types, farming systems, and economic circumstances of the farming community. A major pre-requisite to widespread adoption was low-cost and local manufacturing, repair, and servicing capability. This process is currently being trialed for chickpea, lentil, and other crops in northern Iraq and Syria where, based on low-cost Indian designs, minimum tillage planters are now being locally manufactured and increasingly used (Piggin 2009).

In areas where four-wheel tractors are not so widely available, but two-wheel power tillers are widespread, such as in Bangladesh and Nepal, prospects for converting to minimum tillage have recently risen. An evolutionary process has begun, from using power tillers for complete rotary tillage, through to mounting seed boxes on the rotary tiller (power-tiller-operated seeder), to the reduction or elimination of rotary tillage with delivery of seed and fertilizer behind tines (Hossain et al. 2009; Haque et al. 2010). There are two options for the latter; strip tillage, which leaves only one set of rotor blades directly in front of each tine delivering seed and fertilizer, or zero tillage by completely eliminating rotary tillage. Due to the limited traction of power tillers (usually 12 or $16 \mathrm{hp}$ ), zero tillage is only feasible on lighter textured soils, but strip tillage is effective on heavier soils as the rotor blades not only make the furrow for the following tine but also assist traction and provide a micro-catchment for water infiltration. There are 


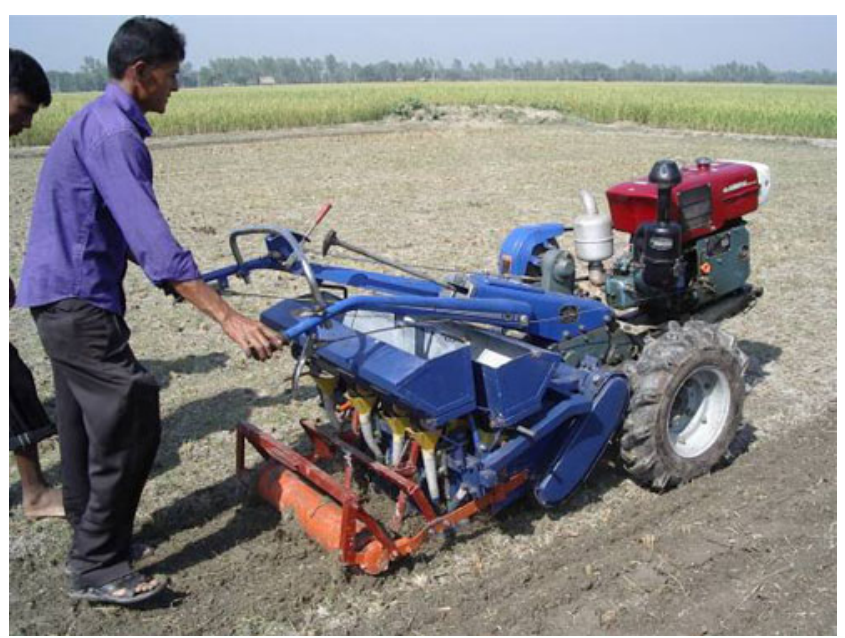

Fig. 2 Versatile multi-crop planter (VMP), with seed and fertilizer delivery attachments fitted to a Chinese-made two-wheel tractor (power tiller), sowing lentil by strip tillage after rice, Bangladesh, November 2009 . The machine can be easily modified to sow by zero tillage (all rotary blades removed), full tillage (all rotary blades present), and to sow on beds

units available that are readily interchangeable between traditional full rotary tillage, power-tiller-operated seeder, strip tillage, and zero tillage (Fig. 2; Enamul Haque, CIMMYT, Bangladesh, personal communication). The strip and zero-tillage options have been developed since 2005 during an Australian Centre for International Agricultural Research project on promoting chickpea and lentil in northwestern Bangladesh. The strip and zero-tillage seeders were initially developed to handle chickpea and lentil seed, but to be commercially viable they need to be able to sow seed of most crops grown in the region. With adjustments to seed metering devices and delivery mechanisms, this requirement has been met, even to the extent of handling primed (pre-soaked) seed (Haque et al. 2010).

Foregoing complete tillage in smallholder systems will, in most soils, require alternative methods of weed management. Hand weeding alone will not suffice as the increased weeding requirement negates the reduced labor requirement and input costs offered by conservation agriculture. This would suggest the requirement for herbicides, but this remains problematic particularly for resource-poor smallholder farmers. There are on-going problems of timely availability and affordability of effective products, and their controlled use to prevent development of herbicide resistance and toxicities to non-target organisms. For weed control in organic agriculture systems, where tillage is not excluded, Bàrberi (2002) stressed the need to develop system-oriented weed management systems. This involves a holistic understanding of crop/weed ecology and using rotations, cover crops, sowing time/procedure, use of competitive crop genotypes, planting pattern, and fertilizer strategy to minimize weed competition.
A change to conservation tillage (minimum or zero tillage), along with adequate weed management, should alone be attractive to smallholder farmers due to reduced costs of land preparation and the many advantages of more precise placement of seed and fertilizer. However, this would provide an opening for the other two main pillars of conservation agriculture - ground cover and crop rotation. The reduced requirement for draft animals reduces the need for crop residue as fodder, releasing residue for use as a ground cover, with legume residue being of greater value. The advantages of including legumes in the rotation, especially in cereal-cereal rotations, would then become more apparent. With increasing demand from farmers for legume components in their cropping patterns, it would become easier to introduce technologies required for their yield maximization.

\section{Increasing water and nutrient use efficiency}

Recent research has indicated scope for increasing water use efficiency (WUE) and nutrient use efficiency (NUE) in food legumes through agronomic means. WUE is defined as grain yield per unit of water use, evapotranspiration, or growing-season rainfall. In temperate and Mediterraneantype cropping systems, where legumes are grown on current rainfall, incoming rainfall can be lost as runoff, deep drainage and soil evaporation or used by the crop in transpiration. The combined loss of water by soil evaporation and transpiration is crop evapotranspiration. In subtropical environments where cool-season legumes are generally grown on stored soil moisture from monsoonal or summer rains, soil evaporation is generally a smaller fraction of total evapotranspiration because the soil surface is frequently dry. In general, increased WUE is associated with increased yield and water use after flowering (Loss et al. 1997; Siddique et al. 1998, 2001). In short-season Mediterranean-type environments, species with early flowering, podding, and seed set have higher yields and WUE than those with later flowering, podding, and seed set (Siddique et al. 2001). When the yields and water use of chickpea and lentil were compared over 12 growing seasons at Tel Hadya in Syria, the WUE for grain varied from 1.9 to 5.5 (mean 3.2) $\mathrm{kg} \mathrm{ha}^{-1} \mathrm{~mm}^{-1}$ in chickpea and from 2.1 to 5.2 (mean 3.8) $\mathrm{kg} \mathrm{ha}^{-1} \mathrm{~mm}^{-1}$ in lentil depending on growing season.

Differences among genotypes in transpiration efficiency (grain yield or above-ground biomass per unit crop transpiration) have been demonstrated in a number of legumes - peanut (Hubick et al. 1986), lentil (Matus et al. 1996; Turner et al. 2007), and chickpea (Turner et al. 2007), but not in narrow-leafed lupin (Turner et al. 2007). Such differences are being used in cereal breeding programs in Australia (Richards 2006). However, agronomic practices 
have yielded greater increases in WUE (Turner 2004; Turner and Asseng 2005). One way of increasing WUE in water-limited Mediterranean-type environments is by earlier planting. In faba bean grown at two sites in Western Australia over 2 years, the WUE for grain decreased from 6 to $10 \mathrm{~kg} \mathrm{ha}^{-1} \mathrm{~mm}^{-1}$ from early- to mid-May plantings down to $2-3 \mathrm{~kg} \mathrm{ha}^{-1} \mathrm{~mm}^{-1}$ when planted in late June to early July, that is a decrease from $0.9 \%$ to $1.4 \%$ per day based on measured water use (Loss et al. 1997). Siddique et al. (1998) showed that for each day's delay in planting after 25 May, lentil yields decreased and WUE for grain decreased by $1.3 \%$ to $1.6 \%$ per day in 2 years when growing-season rainfall was about $300 \mathrm{~mm}$. While water use decreased with later planting, grain yield decreased more leading to reduced WUE. Thus, early planting is a key to higher yields and WUE in most years and crops. However, in field pea, planting too early increases the risk of black spot disease and reduced yields, and when lentil was sown before 25 May in Western Australia, WUE decreased (Siddique et al. 1998). Possibly one reason why very early planting reduces WUE is that WUE is also affected by the vapor pressure deficit of the air which decreases in autumn and winter and increases again in spring in the Mediterranean and sub-tropical climates in which cool-season legumes are grown. As discussed above, conservation agriculture with herbicide use at sowing has enabled earlier planting as weeds are no longer removed by cultivation prior to sowing.

Herbicide use or hand weeding increases WUE by reducing the competition for water and nutrients below ground, and by reducing the competition for light above ground, thereby increasing yields. The development of herbicides to remove grasses and broad-leaved weeds in legume crops in recent years has had a major influence on WUE. The important progress in chemical and non-chemical weed control in food legumes is discussed in the next section.

The use of micro-catchments or basins to concentrate rainfall around roots and contour farming to prevent runoff has increased WUE by providing more water for transpiration rather than rainfall being lost as runoff or soil evaporation. Oweis and Taimeh (1996) found that the overall efficiency of small water-harvesting catchments (water used by the crop as a proportion of the rainfall received) varied from $85 \%$ to $7 \%$ depending on the size of the catchment, root zone capacity, and crop water use (Oweis 2005). Studies with chickpea and lentil have shown that supplemental irrigation can significantly increase yields and WUE (Zhang et al. 2000; Oweis et al. 2004). In both chickpea and lentil, yields increased linearly with the amount of water applied, but WUE in chickpea varied with time of planting. With sowing in late November and late February in northern Syria, supplemental irrigation of $80 \mathrm{~mm}$ on average over 4 years increased WUE of chickpea by $11 \%$ from 4.2 to $4.7 \mathrm{~kg} \mathrm{ha}^{-1} \mathrm{~mm}^{-1}$ (late November) and from 4.7 to $5.2 \mathrm{~kg} \mathrm{ha}^{-1} \mathrm{~mm}^{-1}$ (late February), but did not increase the WUE of chickpea of $5.1 \mathrm{~kg} \mathrm{ha}^{-1} \mathrm{~mm}^{-1}$ when sown in mid-January (Oweis et al. 2004). While supplemental irrigation is not always available, where it is available, it is a means of significantly increasing grain legume yields and WUE.

Well-grown food legumes can be self-sufficient in their $\mathrm{N}$ needs and contribute to the $\mathrm{N}$ economy of the entire cropping system by contributing fixed $\mathrm{N}$ to the soil pool and drawing little or none from soil reserves of $\mathrm{N}$ (Walley et al. 2007). However, to reach their growth and $\mathrm{N}$-fixing potential in most agro-ecosystems, they usually require effective rhizobial inoculation (Clayton et al. 2004; Gan et al. 2005) coupled with supplemental inputs of elements such as phosphorus (P), sulfur (S), boron (B), and molybdenum (Mo). Over the last half century, the major paradigm in alleviating nutrient deficiencies in field crops has been the application of inorganic fertilizers to soil. In the case of non-legume crops in commercial farming, large amounts of $\mathrm{N}$ fertilizer in particular have been applied to permit crops to reach their yield potential. Ironically, the relatively cheap cost of $\mathrm{N}$ fertilizer, derived from oil and natural gas during a period in which those commodities were at their cheapest, has discouraged cultivation of legumes as the residual benefits of fixed $\mathrm{N}$ have seemingly become less important. Further, in attempts to maximize yields within a cropping season, excess and untimely applications have been made, leading to nutrient losses from the cropping system, through runoff, erosion, leaching, and volatilization. Therefore, NUE, defined as economic yield per unit of nutrient applied, has declined over time. Further, nutrients lost from the agricultural system have often had detrimental effects on adjacent ecosystems, especially natural ones (Cloern et al. 2007). There has been a focus on maintaining the adequacy of the available, soluble nutrient pool to meet crop growth nutrient needs, to the relative neglect and detriment of supplying power of other pools, such as organic and soil mineral-bound pools. This approach has been favored by low relative costs to date of soluble fertilizers bearing major nutrients and the relative ease of chemical quantification of soluble pools (soil tests) compared with other soil nutrient pools. This paradigm is also largely being followed in developing countries, jeopardizing sustainability of agricultural lands, upon which large proportions of the population continue to directly rely.

As a consequence of decreasing NUE, environmental damage, likely increased relative costs of inorganic fertilizers, and nutrient imbalances arising from the predominant inorganic fertilizer paradigm, alternative strategies for nutrient management of cropping systems are emerging. These have implications for nutrient supplementation of food legumes and the role of legumes in sustaining 
cropping systems at higher levels of NUE while maintaining, and even increasing, the productivity of those systems. One such strategy is the ecosystem-based approach proposed by Drinkwater and Snapp (2007). They argue that the focus on replenishing available nutrient pools with soluble fertilizers has uncoupled N, P, and C cycles, exacerbated nutrient losses from the system, and created a "fertilizer treadmill" due to diminution of microbial-based nutrient cycling. Their proposed ecosystem-based approach tends towards the principles of organic farming, emphasizing nutrient pools other than the immediately available pool, but use of inorganic fertilizer is not precluded in their analysis. Figure 3 conceptually summarizes the differences in flows of $\mathrm{N}$ and $\mathrm{P}$ among the soil-plant pools under conventional cropping systems and the proposed ecosystem-based model. The main features of their strategy are:

- $\quad$ strategic use of a variety of nutrient resources, rather than an overwhelming focus on the soluble nutrient pool and trying to replenish it with soluble inorganic fertilizer application,

- active management of $\mathrm{N}$ and $\mathrm{P}$ soil pools,
Fig. 3 Qualitative representation of $\mathrm{N}$ (green arrows) and $\mathrm{P}$ (blue arrows; blue-green striped $=\mathrm{N}+\mathrm{P}$ ) dynamics in conventional cropping systems (above) and ecosystem-oriented cropping systems (below). Arrow thickness represents relative proportion of nutrient flow. After Drinkwater and Snapp (2007)

\section{Conventional Agriculture}

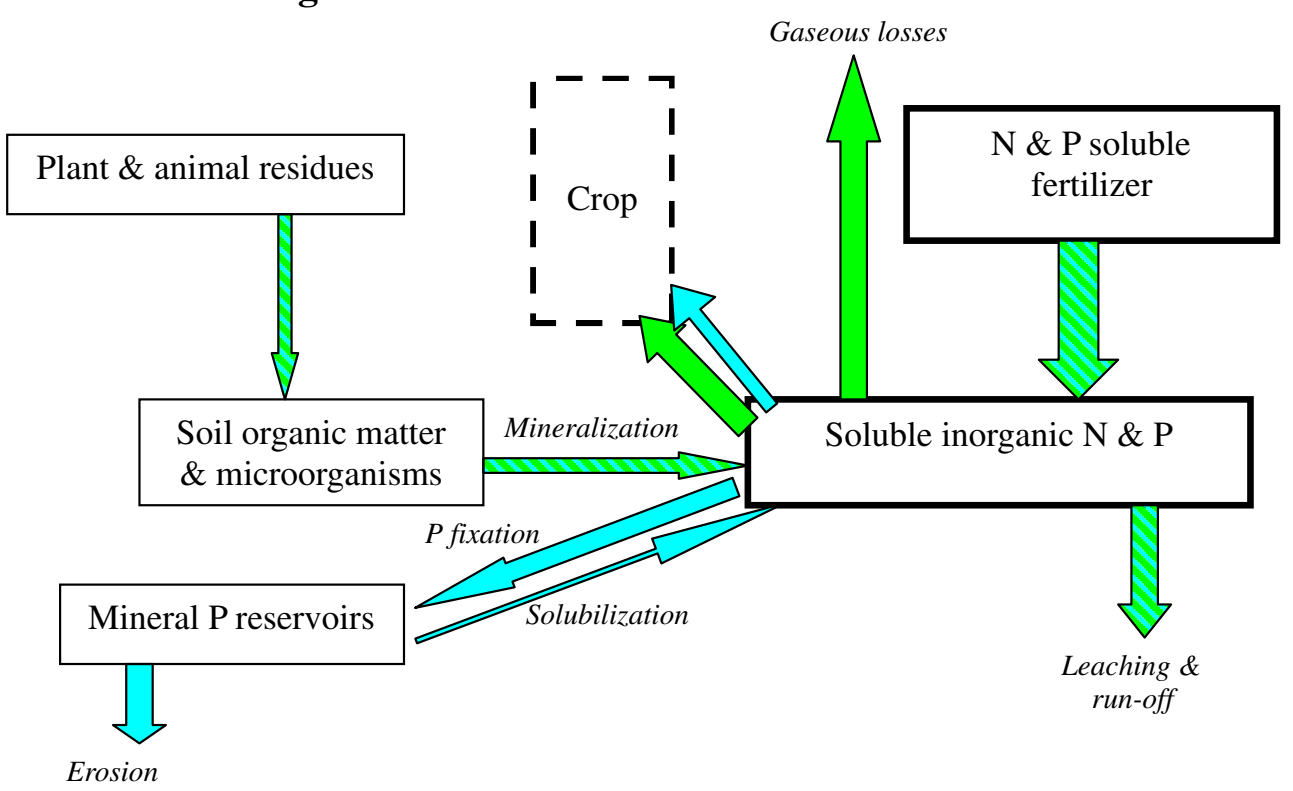

\section{Ecosystem-based Approach}

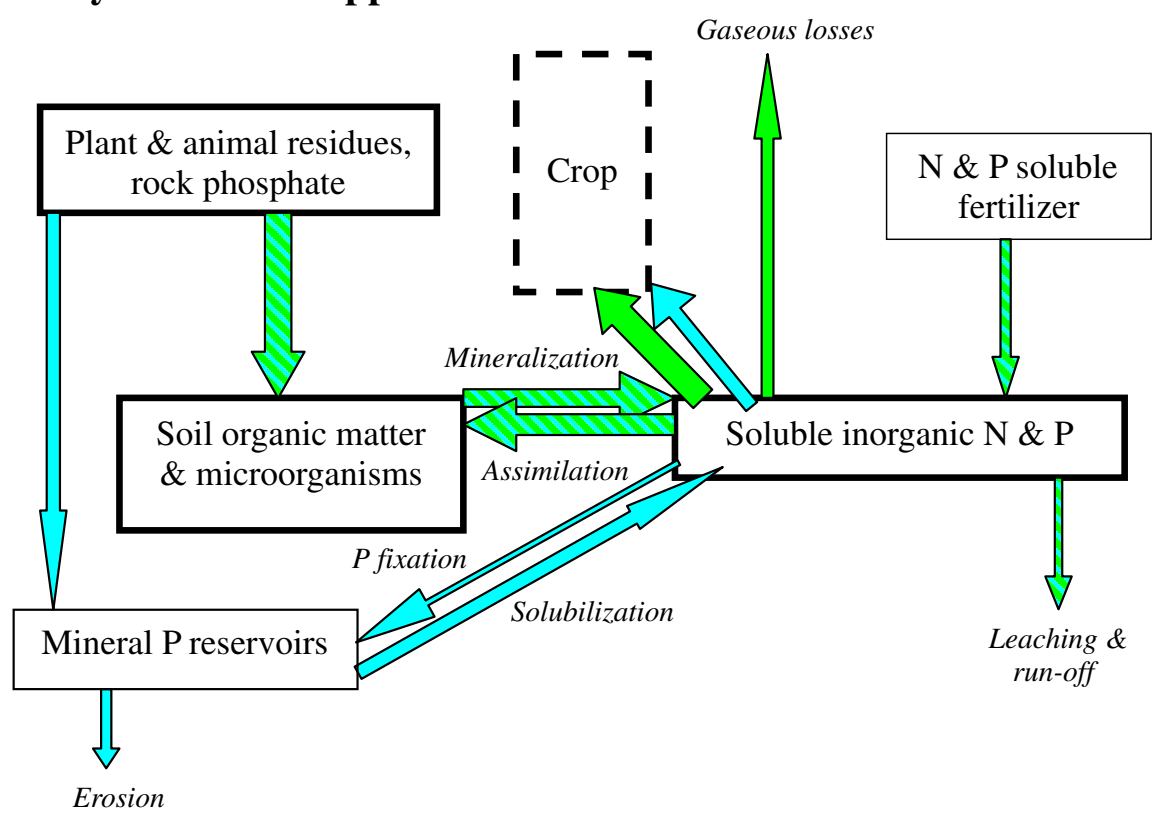


- maximization of $\mathrm{C}$ fixation and $\mathrm{N}$ and $\mathrm{P}$ assimilation in time and space through increased plant diversity in the cropping system,

- promotion of microbial uptake and humification and plant-mediated microbial transformations that supply nutrients. This would result in tighter coupling of nutrient cycles and reduce nutrient losses from the system,

- and, they suggest that the role of the organic P pool in supplying nutrients to plants is underestimated, one reason being its difficulty of measurement, and that the microbial community could be better managed to support plant $\mathrm{P}$ requirements.

This ecosystem-based approach to nutrient use is, by its nature, supportive of greater inclusion of legumes in the cropping system and more effective ways of meeting the nutrient requirements of legume crops. Well-grown, and high $\mathrm{N}$-fixing, legume crops increase the quantum of $\mathrm{C}$ and $\mathrm{N}$ in the soil-plant system, with the $\mathrm{C}$ contributing to microbial activity and the $\mathrm{N}$ in a form which can be mineralized more in concert with future crop $\mathrm{N}$ requirements than sporadic additions of mineral $\mathrm{N}$ fertilizer prone to loss from the system. There is mounting evidence that some legumes increase the pool of available $\mathrm{P}$ in cropping systems by means of root exudates (Bais et al. 2006). In the context of using legumes in conservation agriculture, it should also be mentioned that reduced tillage favors fungal decomposers and enhances $C$ retention (Hobbs et al. 2008).

The ecosystem approach also suggests alternative directions for meeting nutrient needs of legume crops. As for most crops, alleviation of nutrient deficiencies in legumes grown in conventional agriculture has focused on using mineral fertilizers to meet short-term requirements of the available nutrient pool. More emphasis is needed on food legumes better exploiting alternative nutrient pools, such as optimization of mycorrhizal associations (Bucher 2007). Some legumes, such as lupin, are better able to utilize P from partially available sources than other crop species (Braum and Helmke 1995). Phosphorus solubilized from sparingly available sources such as rock phosphate can then, to some extent, be available for following crops (Pypers et al. 2007). This approach should be further pursued, especially in tropical climates due to the effects of temperature on enhancing $\mathrm{P}$ solubilization processes.

A key challenge to healthy growth of food legumes is ensuring adequate nodulation and $\mathrm{N}$ fixation. This requires rhizobial inoculation where there are insufficient effective rhizobia already present in the soil, as occurs for cool season food legumes with their specific requirements for Rhizobium and where legumes are cultivated away from their center of origin, as in Australia. The traditional method of rhizobial inoculation involves applying inoculum to the seed with a sticker or as a peat-based slurry.
However, these methods have various drawbacks such as difficulty in handling and toxicity to rhizobia from seedapplied chemicals. Methods of embedding rhizobia in dry granules of various compositions have evolved and these have proved effective for delivery of optimal Rhizobium numbers (Gan et al. 2005). The advantage of granules is that they permit easy delivery in seed drills and precise placement in the slot in relation to the seed (e.g., slightly displaced if the seed is chemically treated). Denton et al. (2009) evaluated a range of granule types in Australia and found that only attapulgite granules (a clay-peat mix) could match nodulation obtained with peat slurry, but that bentonite granules were not so effective. Nodulation effectiveness was primarily related to rhizobial numbers in the carrier. Other types of Rhizobium inoculation methods have recently evolved, to cope with particular soil conditions. In quick-drying surface soils of the High Barind Tract of Bangladesh, seed priming (overnight soaking of seed in water prior to sowing) of chickpea is required to promote establishment. The surface soil is also acid and chickpea requires Mo. A method of adding Mo and Rhizobium in the priming water has been successfully developed and evaluated on-farm in this region (Johansen et al. 2007).

The ecosystem approach to improving NUE tends towards the principles of organic agriculture, wherein only organic manures or unprocessed rocks (e.g., lime, rock phosphate) are permitted to supplement plant nutrients not already available in the soil (or from the atmosphere in the case of $\mathrm{N}$ fixation by legumes). For some plant nutrients, we have inadequate knowledge of microbial regulation of nutrient dynamics in soil-plant systems to be able to do this very effectively at present. This particularly applies to trace elements where there can be transitions from deficient to toxic concentrations over narrow concentration ranges. For food legumes, as well as other crops, we see an ongoing need for strategic use of chemical fertilizers to alleviate specific nutrient deficiencies but that there should be a concerted effort to maximize supply of required nutrients from organic, unprocessed mineral or existing soil pool sources.

Unfortunately, breeding food legume crops, like most crops, has been invariably carried out in the context of the maximum inorganic fertilizer addition paradigm. It has been argued (Drinkwater and Snapp 2007) that this has resulted in selection against long-evolved mechanisms and plant-microbial associations that permit legumes to retrieve nutrients from sparingly soluble sources. It appears that gains in NUE of target legumes, and the cropping systems in which they grow, could be enhanced by breeding for improved yield under conditions of minimal soluble fertilizer addition and thus greater reliance on microbialdriven nutrient cycling. Initial steps have been taken to breed cereal crops specifically for organic agriculture, realizing that traits and breeding methods different from 
those required for conventional agriculture would be needed (Wolfe et al. 2008). Similar such efforts are needed for food legumes.

\section{Weed, disease, and pest management}

Weeds are a major constraint for legume production both in mechanized broadacre farming systems in advanced countries and labor-intensive smallholder farming systems in developing countries. Most cultivated legumes crops are slow growing in the early stages and prone to weed competition. Competition from weeds may reduce grain legume yields by $25 \%$ to $40 \%$ (Pandey et al. 1998). So, in situations where weeds emerge at the same time as crops, weeds should be controlled within 50 to 70 days after sowing to minimize grain yield loss (Díaz and Peñaloza 1995). Crop-weed competition is complex, yet competition from the crop to reduce impacts of weeds is increasingly seen as important as herbicide availability is restricted. Studies into crop competition show that factors such as weed density, crop variety, crop establishment, seeding rate, and crop rotation can all reduce the impact of weeds on the crop.

Chemicals have come to play a key role in weed management, and without them it is unlikely that food legume crops would have been able to reach their current production levels in extensive agriculture. In developed countries, introduction of selective herbicides together with high yielding and herbicide-tolerant cultivars facilitated rapid adoption of minimum tillage farming systems and revolutionized grain legume production in the late 1980s and early 1990s. Unfortunately, weed control in those countries is now becoming more difficult due to widespread evolution of herbicide-resistant weed biotypes or herbicide contamination of the environment through leaching or surface runoff (Munier-Jolain 2002). Therefore, scarcity of effective herbicide molecules is one of the most serious constraints to legume production in developed countries. The dramatic reduction in area planted to lupins in Australia during the last decade (Fig. 1d) is mainly because weeds are becoming more difficult to manage (Bowran and Hashem 2008). Herbicides that farmers have traditionally relied upon are becoming more expensive as well as less effective due to development of herbicide resistance in weeds such as rigid ryegrass (Llewellyn and Powles 2001) and wild radish (Walsh et al. 2007).

In developing countries, most legume crops are sown by broadcasting seed, and weeds are traditionally controlled manually which requires intensive labor inputs. In addition to a high risk of crop damage, manual weed control is becoming increasingly expensive due to a shortage of labor. Due to increases in cropping intensity in areas where legumes are grown on residual soil moisture, the turn- around time between two crops has reduced considerably. This does not allow farmers to control weeds in a traditional way by several ploughings before sowing legumes. So, in many situations, the application of herbicides for pre-seeding knockdown weed control has seemingly become necessary. Glyphosate (Roundup ${ }^{\circledR}$ ) is now available in some developing countries and can be used for knockdown weed control. However, unregistered (off-label) use of such herbicide molecules by growers with limited or no knowledge of herbicides can result in serious crop damage. Grain legume production in developing countries can potentially be increased if selective herbicides are introduced to control weeds, but this requires extensive education on their proper use and regulatory control.

Some recent advances in innovative chemical and nonchemical weed control research may be helpful for other legume crops and in other parts of the world. Variation exists among cultivars of a legume crop in their ability to compete with weeds. For example, lupin cultivar Mandelup produced $7 \%, 16 \%, 23 \%$, and $30 \%$ more grain yield than cultivar Tanjil in the presence of $0,3,16$, and 28 radish plants per square meter, respectively (Pathan et al. 2006). Increasing plant density increased lentil competitive ability and enhanced the weed suppression effect of mechanical control and chemical control at moderately reduced herbicide rates (Paolini et al. 2003; McDonald et al. 2007). Inter-row annual ryegrass density was reduced by $98-99 \%$ by inter-row application of glyphosate, $64-65 \%$ by inter-row application of Spray Seed ${ }^{\circledR}$ (a mixture of paraquat and diquat), and $53 \%$ by inter-row cultivation, although the risk of crop damage was higher with glyphosate than paraquat+diquat (Hashem et al. 2008). Inter-row cultivation at $5-7.5 \mathrm{~cm}$ from the row using a GPS-mounted tractor caused negligible crop damage but removed $55-77 \%$ weeds in chickpea (Gupta et al. 2008). Repeated mechanical treatments had good weed control, especially the combination of hoeing and weed harrowing (Jensen et al. 2000). Mowing weeds in inter-rows followed by a knockdown spray with a sprayshield improved the control of broadleaf weeds, but had no effect on grass weeds such as annual ryegrass, compared to no mowing followed by a knockdown spray with a sprayshield (Hashem et al. 2004). As a non-chemical option in grain legumes, trimming the heads of weeds that escaped any previous weed control has substantially reduced weed seed production in chickpea and lupin without affecting crop yield (Riethmuller et al. 2009). This can also be achieved by crop-topping, spraying grain legumes with paraquat near maturity to reduce seed set of weeds, but without jeopardizing yield or quality of grain (McMurray 2010).

Trends towards food legume cultivation under conservation agriculture would favor increased herbicide use, but tendencies favoring organic agriculture would exclude this 
option. However, particularly in view of the herbicide resistance problem, there is a scarcity of suitable herbicide molecules in both developed and developing countries. This suggests the need to more aggressively pursue integrated weed management strategies. Where use of herbicides is permissible and feasible in developing countries, there needs to be proper regulation and training options in place so that crop damage, drifts, residues in crops and soils, and opportunities for development of herbicide resistance are minimized. Whether or not herbicides are an option, non-chemical weed control options need to be emphasized. Bàrberi (2002) has summarized integrated weed management strategies that would fit the requirements of organic agriculture (no chemicals) and conservation agriculture (minimum tillage).

Food legume crops are particularly prone to soil-borne and foliar diseases (Allen and Lenné 1998). For some of these diseases, high levels of host plant resistance have been found and resistant varieties developed, such as for Fusarium wilt in chickpea (Haware et al. 1992) and pigeonpea (Reddy et al. 1993). For other diseases, host plant resistance has been partial or unstable thus necessitating management options, sometimes in combination with genotypes with lesser susceptibility, for their alleviation. Examples are ascochyta blight (Ascochyta rabiei), botrytis gray mold (BGM; Botrytis cinerea), and collar rot (Sclerotium rolfsii) in chickpea and lentil (Allen and Lenné 1998). Over recent decades, the first line of defense through management has been use of fungicides, as seed dressings or foliar sprays. While effective in many cases, they are knowledge intensive to use and an increasingly costly input. Further, in developing countries, appropriate fungicides are often not available or too expensive for resource-poor farmers with inadequate local knowledge for their most effective use. Therefore, concepts of integrated disease management (IDM) are increasingly being advocated and implemented for food legumes, in both large-scale commercialized and smallholder agriculture. Many of the candidate components of IDM were established long ago, but their practical use is being encouraged by the increasing severity of some diseases and the need to reduce input costs and the unpredictable effectiveness associated with fungicide use.

Ascochyta blight is the major constraint limiting chickpea production worldwide. Although varieties with partial resistance to the disease have been developed, this resistance is unstable and effective management of the disease relies on agronomic measures. An IDM package for ascochyta blight in chickpea comprises (Gan et al. 2006):

- use of a variety with at least partial resistance

- use of ascochyta blight-free seed and fungicidal seed dressing to reduce the possibility of transmission of this seed-borne disease
- deep burying or burning of chickpea stubble to minimize stubble-borne inoculum (even though this is inconsistent with CA practices!)

- rotation with non-host crops and field isolation from previous chickpea crops, to prevent the spread of ascospores from infected residues

- fungicidal spraying at the seedling stage or prior to the occurrence of the disease

- managing canopy density to minimize canopy conditions conducive to disease development, but without reducing yield loss due to reduced above-ground biomass. This can be achieved by adjusting sowing time and row spacing, intercropping with non-legume crops and avoiding $\mathrm{N}$ fertilizers

- deep sowing (e.g., $>15 \mathrm{~cm}$ ) to create a buffer between infected seed and emerging seedling.

Over the last three decades, the incidence of BGM on chickpea in eastern India, Nepal, and Bangladesh has increased, possibly due to increased irrigation for cereal crops creating more humid microclimates for chickpea growing in the vicinity (Bakr et al. 2002). To address this constraint, based on various component studies, IDM packages for BGM of chickpea have been developed and evaluated under farmer field conditions. Essentially, such IDM packages comprise:

- using a chickpea variety with lesser susceptibility to BGM, as no substantial levels of host plant resistance have yet been identified

- using seed from less BGM-prone environments, or from crops with lesser BGM infection, as the disease is seedborne

- delaying sowing, to prevent excessive vegetative growth which is conducive to disease development

- adjusting plant population so as to prevent a closed canopy which would favor the disease

- close observation of weather conditions that would favor the disease - cloudy, rainy, or foggy weather-to be ready for fungicidal spraying

- observation of indicator plants (e.g., marigolds; Pande et al. 2005a) first affected when spores and weather conditions favor the disease

- need-based foliar application of an effective fungicide (e.g., Bavistin ${ }^{\circledR}$ ).

Evaluations of these packages in Nepal and Bangladesh over the previous decade have demonstrated that resourcepoor farmers in BGM-prone areas can effectively manage BGM of chickpea (Pande et al. 2005b; Johansen et al. 2008). Yields above the national average and with lesser risk of crop failure due to BGM were obtained.

Insufficient levels of host plant resistance have been identified to develop insect "resistant" cultivars of food 
legumes. Two decades ago, hopes were raised for such resistant varieties by the prospects offered by transgenic plants, whereby genes conferring specific resistance to insect pests can be inserted into otherwise acceptable varieties. Examples are insertion of Bt (Bacillus thuringiensis) and trypsin inhibitor genes in chickpea and cowpea (Sharma et al. 2002; Sanyal et al. 2005). While transgenic insect-resistant crops like cotton, maize, etc. are widely used, no such varieties in the target legumes are in farmers' fields. In advanced agriculture, there has not been the pressure to develop transgenic insect-resistant food legumes because they are relatively minor crops and insect constraints usually rank below other constraints, such as disease and drought stress. In developing countries, although there have been attempts to develop transgenic plants, their eventual adoption by farmers seems a distant prospect due to such factors as ongoing political unease about GM crops, the need for refugia and other knowledge intensive management strategies, and dysfunctional seed dissemination systems.

Therefore, integrated pest management (IPM) approaches for insect pests of food legumes continue to rely on management options. In this context, "IPM" refers to insect pests only and is defined here as an optimum combination of insect pest management methods implemented in farmers' fields that minimize economic yield loss of a crop caused by an insect pest or range of pests without resulting in toxic effects on other organisms or otherwise causing an ecological imbalance that would eventually reduce crop yield potential. A longstanding primary, and reflexive, reaction to insect attack has been application of synthetic chemical insecticides. These may be effective in the short term but they usually have longer term adverse consequences, such as development of insect resistance, toxicity to non-target organisms, and increasing economic costs of being on a chemical pesticide treadmill. For example, Helicoverpa armigera, the polyphagous pod borer that is a major enemy of many grain legume crops in South Asia, has developed $>1,000$-fold resistance to pyrethroid insecticides in southern and central India (Kranthi et al. 2001). With an apparent realization of the adverse effects of over-reliance on synthetic chemical insecticides there is now evidence of concerted attempts to minimize their role in cultivation of food legumes.

Global sales of biological (virus, bacteria, nematodes, parasitoids) and botanical (plant extracts, e.g., neem) insecticides are increasing, undoubtedly stimulated by increasing regulatory control of chemical insecticides. For example, in Australia, sprays of $\mathrm{Bt}$ and Helicoverpa nuclear polyhedrosis virus (HNPV) are now considered the preferred insecticides against Helicoverpa species, which are major pests of grain legumes, as well as other crops like cotton, sorghum, etc. (Mensah et al. 2005). In India, biological-control-based IPM management packages have been successfully evaluated in farmers' fields for various crops, including chickpea (Singh et al. 2003). As an example of an IPM package for chickpea, one that is recommended in northern Bangladesh comprises (Harris et al. 2008):

- growing chickpea as a mixed crop, particularly with barley, linseed, or coriander. This discourages oviposition by Helicoverpa moths and encourages natural enemies of pod borer, such as wasps

- checking chickpea fields every few days from the preflowering stage for signs of pod borer activity, such as eggs, leaf scarring, and small larvae

- if one or more larvae $>1 \mathrm{~cm}$ long are on average found per square meter, the following action is required to prevent yield loss:

- place bird perches throughout field at about $10 \mathrm{~m}$ intervals

- if available, spray HNPV at the rate of 250 larval equivalents (LE) per hectare

- repeat HNPV spray if larval numbers increase to $>1 \mathrm{~m}^{-2}$

- if HNPV is not available, or is not effective after two sprays, use a synthetic chemical insecticide

- if it rains soon after spraying, repeat the spray as soon as it appears that the rain has ceased.

The effect of applying this IPM technique on a chickpea crop in Bangladesh is illustrated in Table 1. The low yields eventually realized are mainly attributable to drought stress.

An important ingredient of IPM is the ability to recognize the pest early enough to take effective action. This invariably requires farmer training in pest recognition and its ecology, a knowledge-intensive exercise. The implementation of farmer field schools has proven effective for IPM of rice and some other crops (van den Berg 2004), and the concept needs to be extended to include food legumes.

\section{Integrated crop management}

Much of crop science, and science generally, involves studies on various levels of a single, or at best a few, factors

Table 1 Effect of IPM on the incidence of larvae, percentage of bored pods and on grain yield of a sole crop of chickpea in the High Barind Tract of Bangladesh, 2004-2005

\begin{tabular}{lcll}
\hline Variable & No IPM & IPM & Probability \\
\hline Larvae (no. m $\left.{ }^{-2}\right)$ & 1.71 & 0.27 & $<0.001$ \\
Bored pods $(\%)$ & 15.9 & 5.9 & $<0.001$ \\
Grain yield $\left(\mathrm{t} \mathrm{ha}^{-1}\right)$ & 0.57 & 0.66 & $<0.002$ \\
\hline
\end{tabular}

From Harris et al. (2008) 
keeping other possible yield-determining factors constant. This traditional, reductionist approach has increased our understanding of the major yield-limiting factors to crop yield. However, if farmers are to benefit from this component knowledge, it must be integrated into an overall crop management process, accounting for interactions between factors. The different levels of knowledge integration are shown in Fig. 4. We are primarily concerned with reaching the level of integrated crop management (ICM), but there are also levels of increasing complexity above that (Fig. 4).

In general, grain legumes are more sensitive to biotic and abiotic stresses than other crops and are often confronted with several major constraints simultaneously. For each individual constraint there is usually a research output available for its alleviation, but these potential solutions are less likely to reach smallholder farmers in resource-poor situations. It is suggested that the necessary steps in upward integration as depicted in Fig. 4 are not adequately considered. It is simply assumed that potential solutions identified in component research will somehow find their way to those in need of such solutions. For food legumes particularly, a systematic approach is required firstly in identifying the constraints and eventually assembling a management package to alleviate them. This approach is recommended as follows:

1. Environmental characterization of target area, and possible spillover areas

2. Constraint survey across farmers' fields

3. Diagnostic on-farm trials to identify major yieldconstraining factors

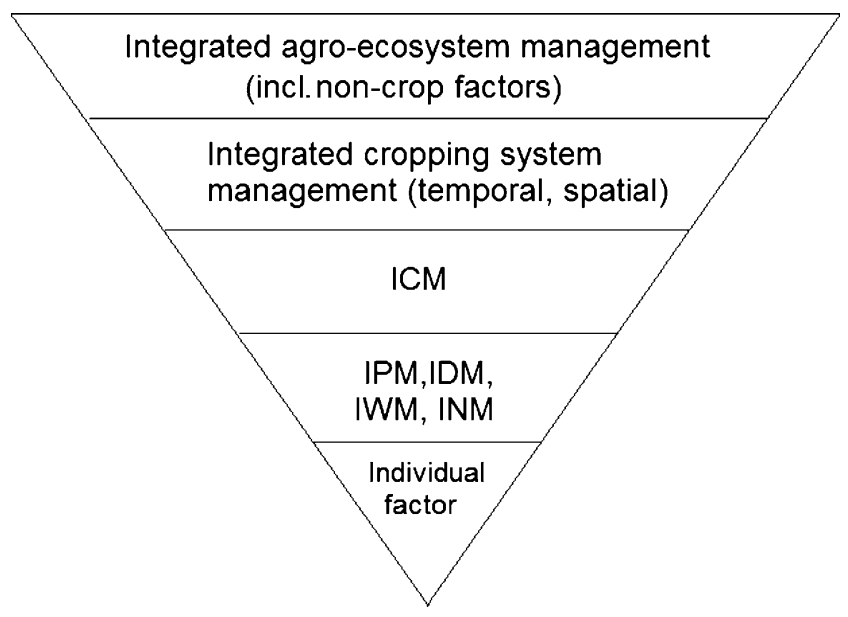

Fig. 4 Integration hierarchy, increasing in complexity, from individual factor responses to integrated agro-ecosystem management. ICM integrated crop management, IPM integrated pest management, IDM integrated disease management, $I W M$ integrated weed management, INM integrated nutrient management
4. On-farm trials with different treatment levels for each major factor, and interactions with other major factors

5. Multilocation evaluation of improved treatments or treatment combinations in operational-scale plots (plots large enough to represent a farmer's typical field)

6. Comparison of improved ICM package with existing practice in operational-scale plots

7. Marginal return calculation for the innovation

8. Large-scale demonstration

9. Adoption and impact analysis, with feedback to bottlenecks.

The first step relies on existing databases of soil, climate, land use, socioeconomic factors, etc. All remaining steps should be conducted in farmers' fields in the defined target environment, with farmer participation at each step. This approach differs from conventional approaches taken by publicly funded agricultural research in most developing countries in that experimentation with different levels of one or several factors usually occurs in fenced-off experimental stations. These provide a different environment to farmers' fields, probably rendering the responses obtained different to what would be obtained in farmers' fields. The argument against conducting controlled experiments in farmers' fields is their lack of "control", but it is suggested that this defect is adequately compensated for by the relevance of the responses obtained to an eventual ICM package. However, whether experimentation is done onstation or on-farm, extensive on-farm multilocation evaluation of putative improved treatments is needed before they can be accepted into an ICM package. There are many instances where this is not being done, with a tendency to leap from a component study to a recommendation for inclusion in ICM. This results in ICM packages with excessive inputs, not all of which would be cost effective and thus decreasing marginal returns on investment in inputs. Further, it should be realized that ICM packages are necessarily dynamic, as new concepts or technologies present themselves for testing and as the farming environment changes.

Examples of implementation of an ICM approach to enhance production of food legumes are the cases of chickpea rehabilitation in BGM-prone areas of Bangladesh and Nepal (Pande et al. 2005b; Johansen et al. 2008). Although BGM was a major constraint in the target region, there were also other serious constraints of pod borer (Helicoverpa armigera), nutrient deficiencies (mainly P and B), root and seedling diseases, and poor quality seed. Thus, ICM packages developed comprised:

- measures to manage BGM, as mentioned under the IPM discussion above

- measures to manage pod borer, as mentioned under the IPM discussion above 
- application of triple superphosphate (TSP) at $100 \mathrm{~kg} \mathrm{ha}^{-1}$; and $\mathrm{B}$ at $1 \mathrm{~kg} \mathrm{ha}^{-1}$ in Nepal

- use quality seed of an appropriate variety

- seed fungicidal treatment to minimize collar rot (caused by Sclerotium rolfsii)

Component responses to each of these inputs, apart from the need for TSP which is yet to be systematically evaluated in the target regions, were evaluated in on-farm experiments to determine their effectiveness under farmers' conditions. Only then were they included, or retained, in the ICM package.

Pande et al. (2005b) found that, during the 1998-1999 to 2000-2001 seasons, chickpea yields in on-farm evaluations (paired plots of ICM compared with farmer practice) in Nepal were about double those with normal farmer practice for chickpea cultivation, and that subsequent adoption of ICM by farmers was substantial. In Bangladesh, district mean yields in on-farm evaluations during 2002-2003 to 2004-2005 and in demonstration plots in 2003-2004 and 2004-2005 always exceeded those in adjacent farmer plots (Johansen et al. 2008). In relative profitability calculations done for the 2005-2006 season, use of chickpea ICM was more profitable than competing irrigated cereal crops and increased net return by almost $50 \%$ over chickpea cultivated by usual farmer practice (Table 2). Due to the low incidence of BGM in this particular season, even chickpea grown with farmer practice was more remunerative than competing irrigated cereal crops due to a combination of low input costs and high grain prices for chickpea.

\section{Improved legume agronomy for resource-poor farmers}

Although recent innovations in agronomy for food legumes are apparent, and are evolving, their slow rate of dissemination among resource-poor smallholder farm-

Table 2 Relative profitability of chickpea, cultivated using either integrated crop management (ICM) or farmer practice (FP), boro rice (grown with irrigation in winter/spring), wheat, and maize in western Bangladesh, based on prices applicable to the 2005-2006 post-rainy season, and mean input levels and yields

\begin{tabular}{llllll}
\hline Item & $\begin{array}{l}\text { Chickpea } \\
\text { ICM }\end{array}$ & $\begin{array}{l}\text { Chickpea } \\
\text { FP }\end{array}$ & $\begin{array}{l}\text { Boro } \\
\text { rice }\end{array}$ & Wheat & Maize \\
\hline Input cost & 10,175 & 7,500 & 31,835 & 21,330 & 33,625 \\
Total income & 40,700 & 30,500 & 46,500 & 31,200 & 54,000 \\
Net return & 30,525 & 23,000 & 14,665 & 9,870 & 20,375 \\
\hline
\end{tabular}

Values are Bangladeshi Taka/ha where US\$ $1=$ Taka 69. From Johansen et al. (2008) ers is of concern and deserves further analysis. In developed country agriculture, innovations for food legume cultivation reach farmers' fields relatively quickly. This is because of the education status, resource and communication availability of target farmers, and the relatively closed and dynamic feedback loop among researchers and farmers. In such systems, much of the funding for agricultural research comes from industry levies or research is conducted in the private sector by input suppliers, and there is thus greater accountability of researcher output to on-farm needs. However, most production of target food legumes occurs in developing countries in smallholder systems (Fig. 1), and it is here that the need for increased production and the technological innovation to do so is greatest. However, these systems are characterized by discontinuities between research, extension, and farmer practice, which retard the flow of technology to farmers. A top-down process remains, from researchers to farmers, with little accountability of researchers to the supposed ultimate clients, the farmers. To catalyze the flow of genetic and agronomic innovations to resource-poor farmers, which will substantially improve production and profitability of food legumes, alternative paradigms of technology generation and transfer are required.

A first requirement in hastening technology transfer to resource-poor farmers is to understand the value addition chain for the commodities in question, even if they remain largely subsistence crops. This can be done by a sub-sector analysis whereby each step in the value addition chain, from input supply through on-farm production, post-harvest processing, and marketing to consumers (or self-consumption in subsistence systems), is mapped. Each step can be quantified in terms of quantities involved, price, numbers of households, value addition, opportunity cost, etc. This permits identification of bottlenecks to the smooth flow from input supply to consumption and suggests priorities and strategies for alleviating those bottlenecks. An example of this approach is a sub-sector analysis for lentil and chickpea in north-western Bangladesh (Amin et al. 2009), where major bottlenecks to increasing production of grain legumes in this region were:

- inadequate flow of knowledge of existing technology to farmers

- lack of local availability of some essential inputs (e.g., quality seed of improved varieties, Rhizobium inoculum, etc.)

- lack of village-level storage and dehusking facilities to add value to harvested grain

- subsidies favoring competing crops, particularly irrigated cereals 
- isolation from global and local market information allowing for more rational planting decisions for these legumes.

Although there were major biophysical constraints to yield and stability of lentil and chickpea in the region, technology to alleviate them was available, at least to some extent, but not being implemented by farmers for the above reasons. It was concluded that if production of lentil and chickpea was to be increased in the target region, the priority would be to address these major bottlenecks, rather than give priority to further research on alleviating biophysical limitations (Amin et al. 2009).

Even though in this example lentil and chickpea are largely grown as subsistence crops, a business development services (BDS) approach (Levitsky 2001) was considered as most relevant to increasing their production and profitability. Sustainable supply of inputs is only likely to occur if they become commercially viable, if adequate profits for their sale are made by suppliers and if farmers understand the profit margin in their use. This requires education of both farmers and suppliers in the technologies and profit margins involved. In such circumstances, suppliers would take over the role of demonstrating these inputs to farmers from publicly funded demonstrations, as occurs in developed country agriculture. However, catalytic public funding is required for initial training of suppliers in input technology and how to demonstrate it to farmers. Public-funded input would then shift towards providing market intelligence, which is becoming increasingly feasible with the generally rapid expansion of communication facilities even into the most remote of rural areas.

In circumstances where further research input to alleviate biophysical bottlenecks is a priority, farmer-participatory on-farm research and development approaches are required, as described above in developing ICM packages. The involvement of resource-poor farming families at all stages of the research-to-adoption continuum encourages a feeling of ownership by those families of any promising technologies developed. This creates a greater chance of their adoption compared with technologies handed down in a top-down approach. It also provides a mechanism of immediate feedback to researchers to the priority researchable constraints and appropriate methodology to achieve solutions relevant to target farming households.

Limitations of traditional top-down approaches to international agricultural development were realized 25 years ago (e.g., Chambers 1985), but such approaches remain dominant to this day, impeding technology flow to growers of food legumes most in need of technological assistance. For resource-poor farmers in developing countries, there is considerable existing knowledge that would permit them to substantially raise yields and stability of yield of food legume crops. Realization of existing technological innovations among resource-poor farming communities depends on changing research and development paradigms such that they become more accountable to end users.

\section{Conclusion}

Food legumes are normally grown in rainfed, droughtprone environments. Recent advances in understanding how to improve WUE in food legumes, aided by an everincreasing ability to model soil-water-plant systems, increase our capability to cope with risks associated with drought-prone environments. This is necessary if food legume cultivation is to continue or increase into a period of climate change, with likelihoods of more extreme weather events. Moves toward more ecological-based approaches in managing nutrition, weeds, diseases, and pests of food legumes also offer prospects for greater inclusion of food legumes in cropping systems. In effect, this is indicative of increasing acceptance of the components of organic agriculture, but not necessarily to the complete exclusion of synthetic chemical inputs. Conservation agriculture perhaps offers a more realistic framework for incorporating ecological approaches to management of the major abiotic and biotic constraints of food legumes, with judicious reliance on synthtetic chemical inputs. However, a major challenge remains in developing effective methods of weed management without reliance on either herbicides or thorough tillage. Nevertheless, increasing adoption of conservation agriculture, like organic agriculture, should encourage greater incorporation of these legumes in various cropping systems. Although adoption of conservation agriculture is widespread in large-scale commercial agriculture, it is only at initial stages in resourcepoor smallholder situations. However, recent advances introducing minimum tillage concepts in these situations offer concomitant advantages for food legumes.

A boost in food legume production by resource-poor farmers is a dire necessity due to static or declining production trends for most of these commodities in developing countries, yet increasing global demand for legume grain. Technology to substantially increase and stabilize yields of food legumes in most areas is available but its rapid adoption appears restricted to industrialized agriculture. Here, there are closed feedback loops among researchers, growers, and consumers facilitating rapid dissemination of improved technology to farmers. A topdown approach in delivering technology to resource-poor smallholder farmers persists, causing discontinuities between research, extension, and farmers, and thus impeding 
movement of agricultural technology to these rural communities. It is proposed that transfer of long-established and recently developed technologies related to food legume production to resource-poor rural communities could be hastened with more participatory approaches. A prerequisite would be comprehensive understanding of the value addition chain for the particular subsector to better understand the bottlenecks involved. To address problems of crop production, it is proposed that an on-farm approach is necessary, with involvement of the local farming community from the diagnosis and research phase, and merging into the evaluation, extension, and adoption phases. The challenge is for resource-poor farmers to take ownership of innovations in food legume agronomy.

Acknowledgment We thank Dr. Sabine D. Golombek, Kirchen, Germany, for assistance with figure preparation.

\section{References}

Abrol IP, Bronson KF, Duxbury JM, Gupta RK (Eds.) (2000) Longterm soil fertility experiments in rice-wheat cropping systems. Rice-Wheat Consortium Series Paper Series 6. Rice-Wheat Consortium for the Indo-Gangetic Plains. New Delhi, India

Allen DJ, Lenné JM (1998) The pathology of food and pasture legumes. CABI, Wallingford

Amin MA, Bani Johansen C, Musa AM, Neogi MG, Haque M Enamul. (2009) Sub-sector analysis of lentil and chickpea in North-western Bangladesh. A Project Report of ACIAR Project LWR/2005/001 "Addressing constraints to pulses in cerealsbased cropping systems, with particular reference to poverty alleviation in north-western Bangladesh" pp 41

Armstrong-Cho C, Wolf T, Chongo G, Gan Y, Hogg T, Lafond G, Johnson E, Banniza S (2008) Effect of carrier volume on ascochyta blight (Ascochyta rabiei) control in chickpea. Crop Protect 27:1020-1030

Aw-Hassan AA, Regassa S, Shafiqul Islam QM, Sarkar A (2009) The impact of improvement research: the case of Bangladesh and Ethiopia. In: Erskine W, Muehlbauer FJ, Sarker A, Sharma B (eds) The lentil: botany production and uses. CABI, Wallingford, pp 425-446

Bais HP, Weir TL, Perry LG, Gilroy S, Vivanco JM (2006) The role of root exudates in rhizosphere interactions with plants and other organisms. Ann Rev Plant Biol 57:233-266

Baker CJ, Saxton KE, Ritchie WR, Chamen WCT, Reicosky DC, Ribeiro MFS, Justice SE, Hobbs PR (2006) No-tillage seeding in conservation agriculture, 2nd edn. CABI/FAO, Oxford

Bakr MA, Siddique KHM, Johansen C (Eds.) (2002) Integrated management of Botrytis grey mould of chickpea in Bangladesh and Australia: summary proceedings of a Project Inception Workshop, 1-2 June 2002, Bangladesh Agricultural Research Institute (BARI), Joydebpur, Gazipur, Bangladesh. BARI, Joydebpur, Gazipur, Bangladesh; and Centre for Legumes in Mediterranean Agriculture, Crawley, Western Australia 6009, pp 138

Bàrberi P (2002) Weed management in organic agriculture: are we addressing the right issues? Weed Res 42:177-193

Biederbeck VO, Zentner RP, Campbell CA (2005) Soil microbial populations and activities as influenced by legume green fallowing in a semiarid loam. Soil Biol Biochem 37:1775-1784
Bolliger A, Magid J, Amado JCT, Neto FS, Ribeiro MFS, Caligari A, Ralisch R, Neergaard A (2006) Taking stock of the "Brazilian Zero Till" revolution: a review of landmark research and farmers' practice. Adv Agron 91:47-110

Bowran D, Hashem A (2008) The role of weed management in sustaining systems for lupin production. In: Palta JA, Berger JB (eds) Lupins for Health and Wealth Proceedings of the 12th International Lupin Conference 14-18 Fremantle, Australia. International Lupin Association, Canterbury, pp 11-14

Braum SM, Helmke PA (1995) White lupin utilizes soil phosphorus that is unavailable to soybean. Plant Soil 176:95-100

Bucher M (2007) Functional biology of plant phosphate uptake at root and mycorrhiza interfaces. New Phytol 173:11-26

Challinor AJ, Wheeler TR, Craufurd PQ, Ferro CAT, Stephenson DB (2007) Adaptation of crops to climate change through genotypic responses to mean and extreme temperatures. Agric Ecosys Environ 119:190-204

Chambers R (1985) Agricultural research for resource-poor farmers: the farmer-first-and-last model. Agric Admin 20:1-30

Chandirasekaran R, Warkentin T, Gan YT, Shirtliffe SJ, Gossen DB, Taran B, Banniza S (2009) Improved sources of resistance to ascochyta blight in chickpea. Can J Plant Sci 89:107-118

Christensen JH, Hewitson B, Busuioc A, Chen A, Gao X, Held I, Jones R, Kolli RK, Kwon W-T, Laprise R, Magaña Rueda V, Mearns L, Menéndez CG, Räisänen J, Rinke A, Sarr A, Whetton P (2007) Regional climate projections. In: Solomon S, Qin D, Manning M, Chen Z, Marquis M, Averyt KB, Tignor M, Miller HL (eds) Climate Change 2007: the physical science basis. Contribution of Working Group I to the Fourth Assessment Report of the Intergovernmental Panel on Climate Change. Cambridge University Press, New York

Clayton G, Rice WA, Lupwayi NZ, Johnston AM, Lafond GP, Grant CA, Walley F (2004) Inoculant formulation and fertilizer nitrogen effects on field pea: nodulation, nitrogen fixation and nitrogen partitioning. Can J Plant Sci 84:79-88

Cloern J, Krantz T, Duffy JE (2007) Eutrophication. In: Cleveland CJ (Ed.), Encyclopedia of Earth. Environmental Information Coalition, National Council for Science and the Environment, Washington, DC, USA. Available at http://www.eoearth.org/ article/Eutrophication. Last revised December 18, 2007; accessed March 9, 2010

Cooper P, Rao KPC, Singh P, Traore PS, Rao K, Dixit P, Twomlow SJ (2009) Farming with current and future climate risk: advancing a 'Hypothesis of Hope' for rainfed agriculture in the semi-arid tropics. J SAT Agric Res 7, pp 19. Available at http://ejournal. icrisat.org/aerpaperv 7.htm

Crowe T, Brand J (2010) The role of pulses in the no-till system. Pulse Update Annual 2010 No. 9, p. 10

Denton MD, Pearce DJ, Ballard RA, Hannah MC, Mutch LA, Norng S, Slattery JF (2009) A multi-site field evaluation of granular inoculants for legume nodulation. Soil Biol Biochem 41:25082516. doi:10.1016/j.soilbio.2009.09.009

Derpsch R (2002) Making conservation tillage conventional, building a future on 25 years of research: research and extension perspective. Proceedings of 25th Annual Southern Conservation Tillage Conference for Sustainable Agriculture, Auburn, AL, USA, 24-26 June, 2002, pp 25-29

Derpsch R (2005) The extent of conservation agriculture adoption worldwide: implications and impact. In Proceedings of the Third World Congress on Conservation Agriculture: Linking Production, Livelihoods and Conservation, Nairobi, Kenya, 3-7 October $2005[\mathrm{CD}]$

Díaz SJ, Peñaloza HE (1995) Critical period of weed interference in dry peas (Pisum sativum L) cv Progreta and lentil (Lens culinaris M) cv Araucana-INIA. Agricultura Técnica Santiago $55: 176-182$ 
Drinkwater LE, Snapp SS (2007) Nutrients in agroecosystems: rethinking the management paradigm. Adv Agron 92:163-186. doi:10.1016/S0065-2113(04)92003-2

FAO (Food and Agriculture Organization of the United Nations) (2010) FAOSTAT. Statistical database of FAO, Rome. Available at http://faostat.fao.org/default.aspx. Accessed 26 Jan 2010

Gan Y, Miller PR, McConkey BG, Zentner PR, Stevenson FC, McDonald CL (2003) Influence of diverse cropping sequences on durum wheat yield and protein in the semiarid northern Great Plains. Agron J 95:245-252

Gan Y, Hanson KG, Zentner RP, Selles F, McDonald CL (2005) Response of lentil to microbial inoculation and low rates of fertilization in semiarid Canadian prairies. Can J Plant Sci $85: 847-855$

Gan YT, Siddique KHM, MacLeod WJ, Jayakumar P (2006) Management options for minimizing the damage by aschochyta blight (Ascochyta rabiei) in chickpea (Cicer arietinum L.). Field Crops Res 97:121-134

Gan YT, Warkentin T, Chandirasekaran R, Gossen DB, Wolf T, Banniza S (2009) Effects of planting pattern and fungicide application systems on ascochyta blight control and seed yield in chickpea. Agron J 10:1548-1555

Gan Y, Kutcher HR, Menalled FD, Lafond G, Brandt SA (2010) Crop diversification and intensification with broadleaf crops in cerealbased cropping systems. In: Malhi SS, Gan YT, Schoenau JJ, Lemke R, Liebig MA (eds) Recent trends in soil science and agronomy research in the Northern Great Plains of North America. Research Signpost, Trivandrum, pp 277-301

Gatel P (1994) Protein quality of legume seeds for non-ruminant animals: a literature review. Anim Feed Sci Tech 45:317-348

Giller KE, Witter E, Corbeels M, Tittonell P (2009) Conservation agriculture and smallholder farming in Africa: the heretics' view. Field Crops Res 114:23-34. doi:10.1016/j.fcr.2009.06.017

Gross Y, Kigel J (1994) Differential sensitivity to high temperature of stages of the reproductive development of common bean (Phaseolus vulgaris L.). Field Crops Res 36:201-212

Gupta ML, George DL, Norton L (2008) Precision guided mechanical weed control. Proceedings of the 16th Australian Weeds Conference, Cairns Convention Centre, North Queensland, Australia, 18-22 May, 2008. Queensland Weed Society, Queensland, Australia, p. 222

Hall AE (1992) Breeding for heat tolerance. Plant Breed Rev 10:129-167

Haque ME, Esdaile RJ, Kabir E, Vance W, Bell RW, Musa AM, Shahidullah AKM, Nur Nobi Mia M, Maruffuzaman M, Johansen C (2010) Minimum-tillage, mechanized sowing of pulses with two-wheel tractors. In: Gilkes RJ, Nattaporn Prakongkep (eds) Symposium 3.1.2 Farm system and environment impacts. Proceedings of $19^{\text {th }}$ World Congress of Soil Science, Soil Solutions for a Changing World, Brisbane, Australia, 1-6 August 2010. International Union of Soil Science, Wageningen, The Netherlands, pp 156-159

Harris D, Johansen C, Musa AM (2008) Farmer-friendly technologies to improve chickpea production in the High Barind Tract. In: Riches C, Harris D, Johnson DE, Hardy B (eds) Improving agricultural productivity in rice based systems of the High Barind Tract of Bangladesh. International Rice Research Institute (IRRI), Los Baños, pp 119-133

Hashem A, Collins M, Nicholson D, Roche J, Borger C (2004) Weed control with Spray.Seed ${ }^{\circledR}$ between lupin rows. In: Parker W (ed) Crop update proceedings: weed update held on 18-19 February. Department of Agriculture, Perth, pp 22-23

Hashem A, Douglas A, Pathan S, Peltzer S (2008) Control and seed production of annual ryegrass in wide row lupins systems in Western Australian wheatbelt. Proc. 16th Australian Weeds Conference, Cairns, Australia, 18-22 May, 2008. Queensland Weed Society, Queensland, pp 480-482
Haware MP, Nene YL, Pundir RPS, Narayana RJ (1992) Screening of world chickpea germplasm to fusarium wilt. Field Crops Res 30:147-154

Hawthorne W (2010) Wider row pulses in stubble systems. Pulse Update Annual 9:24

Hobbs PR, Sayre K, Gupta R (2008) The role of conservation agriculture in sustainable agriculture. Phil Trans R Soc B 363:543-555. doi:10.1098/rstb.2007.2169

Hossain I, Esdaile RJ, Bell R, Holland C, Haque E, Sayre K, Alam M (2009) Actual challenges: developing low cost no-till seeding technologies for heavy residues; small-scale no-till seeders for two wheel tractors. In: 4th World Congress of Conservation Agriculture, 3-7 February, 2009, New Delhi, India, pp 171-177

Hubick KT, Farquhar GD, Shorter R (1986) Correlation between water use efficiency and carbon isotope discrimination in diverse peanut (Arachis) germplasm. Aust J Plant Physiol 13:803-816

Jagadish SVK, Craufurd PQ, Wheeler TR (2007) High temperature stress and spikelet fertility in rice (Oryza sativa L.). J Exp Bot 58:1627-1635

Jensen RK, Bo M, Nis C (2000) Lupin, an ancient crop for the new millennium. In: van Santen E, Wink M, Weissmann S, Römer P (Eds.) Proceedings of the 9th International Lupin Conference. Klink/Muritz: Germany, 20-24, pp 76-78

Johansen C, Musa AM, Kumar Rao JVDK, Harris D, Yusuf AM, Shahidullah AKM, Lauren JG (2007) Correcting molybdenum deficiency of chickpea in the High Barind Tract of Bangladesh. J Plant Nutr Soil Sci 170:752-761

Johansen C, Bakr MA, Sirajul IM, Mondal NA, Afzal A, MacLeod WJ, Pande S, Siddique KHM (2008) Integrated crop management of chickpea in environments of Bangladesh prone to Botrytis grey mould. Field Crops Res 108:238-249

Kakani VG, Prasad PVV, Craufurd PQ, Wheeler TR (2002) Response of in vitro pollen germination and pollen tube growth of groundnut (Arachis hypogaea L.) genotypes to temperature. Plant Cell Environ 25:1651-1661

Kranthi KR, Jadhav D, Wanjari R, Kranthi S, Russell D (2001) Pyrethroid resistance and mechanisms of resistance in field strains of Helicoverpa armigera (Lepidoptera: Noctuidae). J Econ Entomol 94:253-263

Lemke RL, Zhong Z, Campbell CA, Zentner RP (2007) Can pulse crops play a role in mitigating greenhouse gases from North American agriculture? Agron J 99:1719-1725

Levitsky J (2001) Business development services in Asian countries. ITDG, London

Li Y, Tullberg JN, Freebairn DM (2001) Traffic and residue cover effects on infiltration. Aust J Soil Res 39:239-247

Liu L, Gan Y, Bueckert R, Van Rees K, Warkentin T (2010) Fine root distributions in oilseed and pulse crops. Crop Sci 50:222-226

Llewellyn RS, Powles SB (2001) High levels of herbicide resistance in rigid ryegrass (Lolium rigidum) in the wheatbelt of Western Australia. Weed Technol 15:242-248

Loss SP, Siddique KHM, Tennant D (1997) Adaptation of faba bean (Vicia faba L.) to dryland Mediterranean-type environments. III. Water use and water-use efficiency. Field Crops Res 54:153-162

Mazvimavi K, Twomlow S, Belder P, Hove L (2008) An assessment of the sustainable uptake of conservation farming in Zimbabwe. Global Theme on Agroecosystems Report No. 19. International Crops Research Institute for the Semi-Arid Tropics, Bulawayo, Zimbabwe, pp 51

Matus A, Slinkard AE, van Kessel C (1996) Carbon isotope discrimination and indirect selection for transpiration efficiency at flowering in lentil (Lens culinaris Medikus), spring bread wheat (Triticum aestivum L.), durum wheat (T. turgidum L.), and canola (Brassica napus L.). Euphytica 87:141-151 
McDonald GK, Hollaway KL, McMurray L (2007) Increasing plant density improves weed competition in lentil (Lens culinaris). Aust J Exp Agric 47:48-56

McMurray L (2010) Late weed control can compromise yield. Ground Cover January-February 2010 Pulse Breeding Supplement. More Pulse Choices. Grains Research and Development Corporation, Kingston, pp 14-15

Mensah RK, Liang W, Gibb D, Coates R, Johnson D (2005) Improving the efficacy of nuclear polyhedrosis virus and Bacillus thuringiensis against Helicoverpa spp with ultra-violet light protected petroleum spray oils on cotton crops in Australia. Intl J Pest Manag 51:101-109. doi:10.1080/09670870400028334

Miller PR, Gan Y, McConkey BG, McDonald CL (2003) Pulse crops for the northern Great Plains: I. Grain productivity and residual effects on soil water and nitrogen. Agron J 95:972-979

Munier-Jolain NM (2002) The long-term impact of grain legumes on the environment: possibilities for reducing herbicides. Grain Legumes 36:16-17

Ndufa JK, Gathumbi SM, Kamiri HW, Giller KE, Cadisch G (2009) Do mixed-species legume fallows provide long-term maize yield benefit compared with monoculture legume fallows? Agron J 101:1352-1362

O'Leary GJ, Conner DJ (2007) A simulation study of wheat crop response to water supply, nitrogen nutrition, stubble retention, and tillage. Aust J Agric Res 49:11-19

Oweis TY (2005) Role of water harvesting and supplemental irrigation in coping with water scarcity and drought in the dry areas. In: Wilhite DA (ed) Drought and water crises: science, technology and management issues. CRC, Baton Rouge, pp 191213

Oweis TY, Taimeh AY (1996) Evaluation of a small basin waterharvesting system in the arid region of Jordan. Water Res Manag 10:21-34

Oweis T, Hachum A, Pala M (2004) Water use efficiency of wintersown chickpea under supplemental irrigation in a Mediterranean environment. Agric Water Manage 66:163-179

Pande S, Kishore GK, Rao JN (2005a) Marigold: a diagnostic tool for BGM forecasting and management in chickpea. Intl Chickpea Pigeonpea Newsl 12:2-3

Pande S, Stevenson PC, Rao JN, Neupane RK, Grzywacz D, Bourai VA, Kishore GK (2005b) Reviving chickpea production in Nepal through integrated crop management, with emphasis on botrytis gray mold. Plant Dis 89:1252-1262

Pandey AK, Prasad K, Singh P, Singh RD (1998) Comparative yield loss assessment and crop-weed association in major winter crops of mid hills of N-W Himalayas. Indian J Weed Sci 30:54-57

Paolini R, Colla G, Saccardo F, Campiglia E (2003) The influence of crop plant density on the efficacy of mechanical and reduced-rate chemical weed control in lentil (Lens culinaris Medik.). Ital J Agron 7:85-94

Pathan SM, French B, Hashem A (2006) Competitiveness of different lupin cultivars with wild radish. In: Douglas A (ed) Agribusiness crop updates (Weeds). Department of Agriculture and Food, Western Australia, Perth, pp 60-64

Piggin C (2009) Improving agriculture with zero tillage cropping systems in Iraq. Issues 89:11-13

Prasad PVV, Craufurd PQ, Summerfield RJ, Wheeler TR (2000) Effects of short episodes of heat stress on flower production and fruit-set of groundnut (Arachis hypogaea L.). J Exp Bot 51:777784

Prasad PVV, Craufurd PQ, Kakani VG, Wheeler TR, Boote KJ (2001) Influence of high temperature during pre- and post-anthesis stages of floral development on fruit-set and pollen germination in peanut. Aust J Plant Physiol 28:233-240

Prasad PVV, Boote KJ, Allen LH, Thomas JMG (2002) Effects of elevated temperature and carbon dioxide on seed-set and yield of kidney bean (Phaseolus vulgaris L.). Glob Change Biol 8:710 721

Prasad PVV, Boote KJ, Allen LH, Thomas JMG (2003) Super-optimal temperatures are detrimental to peanut (Arachis hypogaea L.) reproductive processes and yield at ambient and elevated carbon dioxide. Glob Change Biol 9:1775-1787

Prasad PVV, Boote KJ, Allen LH (2006) Adverse high temperature effects on pollen viability, seed set, seed yield and harvest index of grain-sorghum [Sorghum bicolor (L.) Moench] are more severe at elevated carbon dioxide due to higher tissue temperatures. Agric For Meteorol 139:237-251

Pypers P, Huybrighs M, Diel J, Abaidoo R, Smolders E, Merckx R (2007) Does the enhanced P acquisition by maize following legumes in a rotation result from improved soil $\mathrm{P}$ availability? Soil Biol Biochem 39:2555-2566

Reddy MV, Raju TN, Sharma SB, Nene YL, McDonald D (1993) Handbook of pigeonpea diseases. ICRISAT Information Bulletin 42. ICRISAT, Hyderabad

Richards RA (2006) Physiological traits used in the breeding of new cultivars for water-scarce environments. Agric Water Manag 80:197-211

Riethmuller GP, Hashem A, Pathan SM (2009) Chemical and nonchemical weed control in wide row lupins and chickpeas in Western Australia. Aust J Multidisciplinary Eng 7:15-26

Sanyal I, Singh AK, Kaushik M, Amla DV (2005) Agrobacteriummediated transformation of chickpea (Cicer arietinum L.) with Bacillus thuringiensis cry1Ac gene for resistance against pod borer insect Helicoverpa armigera. Plant Sci 168:1135-1146

Satake T, Yoshida S (1978) High temperature induced sterility in indica rices at flowering. Jap J Crop Sci 47:6-17

Satyanarayana A, Rangaswamy P, Muttaiah R, Patil MS, Reddy MV, Naidu NV, Cheralu C, Ramakrishna A, Chauhan YS (2001) Legumes in tropical rice based cropping systems in Peninsular India. In: Gowda CLL, Ramakrishna A, Rupela OP, Wani SP (eds) Legumes in rice-based cropping systems in tropical Asia: constraints and opportunities. ICRISAT, Patancheru, pp 11-25

Shanmugasundaram S (2006) (Ed.) Improving income and nutrition by incorporating mungbean in cereal fallows in the IndoGangetic Plains of South Asia, DFID Mungbean Project for 2004-2006. Proceedings of the final workshop and planning meeting, Punjab Agricultural University, Ludhiana, Punjab, India, 27-31 May 2004. AVRDC Publication No. 06-682.342. Shanhua, Taiwan: The World Vegetable Center (AVRDC)

Sharma HC, Sharma KK, Crouch JH (2002) Genetic transformation of crops for insect resistance: potential and limitations. CRC Crit Rev Plant Sci 23:47-72

Siddique KHM, Loss SP, Pritchard DL, Regan KL, Tennant D, Jettner RL, Wilkinson D (1998) Adaptation of lentil (Lens culinaris Medik.) to Mediterranean-type environments: effect of time of sowing on growth, yield, and water use. Aust J Agric Res 49:613-626

Siddique KHM, Regan KL, Tennant D, Thomson BD (2001) Water use and water use efficiency of cool season grain legumes in low rainfall Mediterranean-type environments. Eur J Agron 15:267-280

Siddique KHM, Johansen C, Kumar Rao JVDK, Ali M (2008) Legumes in sustainable cropping systems. In: Kharkwal MC (ed) Food legumes for nutritional security and sustainable agriculture Proceedings of the Fourth International Food Legumes Research Conference (IFLRC-IV), October 18-22, 2005, New Delhi, India, vol 1. Indian Society of Genetics and Plant Breeding, New Delhi, pp 787-819

Singh A, Singh S, Rao SN (2003) Integrated pest management in India. In: Maredia KM, Dakouo D, Mota-Sanchez D (eds) Integrated pest management in the Global Arena. CABI, London, pp 209-221

Singh BB, Ehlers JD, Sharma D, Freire Filho FR (2002) Recent progress in cowpea breeding. In: Fatokun CA, Tarawali SA, 
Singh BB, Kormawa PM, Tamò M (eds) Challenges and opportunities for enhancing sustainable cowpea production. Proceedings of the World Cowpea Conference III held at the International Institute of Tropical Agriculture (IITA), Ibadan, Nigeria, 4-8 September 2000. IITA, Ibadan, pp 22-40

Sweetingham M, Kingwell R (2008) Lupins - reflections and future prospects. In: Palta JA, Berger JD (Eds.) Proceedings of the 12th International Lupin Conference, Lupins for Health and Wealth. Fremantle, Western Australia, pp 514-524

Tharanathan RN, Mahadevamma S (2003) Grain legumes-a boon to human nutrition. Trends Food Sci Tech 14:507-518

Thaung NN, Choi KS (2008) Market performance of selected pulses in Myanmar. Asia Pac J Rural Dev 18(2):23-44

Turner NC (2004) Agronomic options for improving rainfall-use efficiency of crops in dryland farming systems. J Exp Bot 55:2413-2425

Turner NC (2008) Adaptation to climate change: research needs for smallholder farmers growing sorghum and pigeon pea in Eastern and Southern Africa. Report commissioned by ICRISAT, East Africa, $29 \mathrm{pp}$

Turner NC, Asseng S (2005) Productivity, sustainability, and rainfalluse efficiency in Australian rainfed Mediterranean agricultural systems. Aust J Agric Res 56:1123-1136

Turner NC, Palta JA, Shrestha R, Ludwig C, Siddique KHM, Turner DW (2007) Carbon isotope discrimination is not correlated with transpiration efficiency in three cool-season grain legumes (pulses). J Integr Plant Biol 49:1478-1483

Vadez V, Kholova J, Choudhary S, Zindy P, Terrier M, Krishnamurthy L, Kumar PR, Turner NC (2011) Whole plant response to drought under climate change. In: Yadav S, Redden R, Hatfield JL, Lotze-Campen $\mathrm{H}$ (eds) Crop adaptation to climate change. Wiley-Blackwell, Ames

Van den Berg H (2004) IPM farmer field schools: a synthesis of 25 impact evaluations. Prepared for the Global IPM Facility. Wageningen University, The Netherlands

Walley FL, Clayton GW, Miller PR, Carr PM, Lafond GP (2007) Nitrogen economy of pulse crop production in the Northern Great Plains. Agron J 99:1710-1718

Walsh MJ, Owen MO, Powles SB (2007) Frequency and distribution of herbicide resistance in Raphanus raphanistrum populations randomly collected across the Western Australian wheatbelt. Weed Res 47:542-550

Wolfe MS, Baresel JP, Desclaux D, Goldringer I, Hoad S, Kovacs G, Löschenberger F, Miedaner T, Østergård $\mathrm{H}$, Lammerts van Bueren ET (2008) Developments in breeding cereals for organic agriculture. Euphytica 163(3):323-346. doi:10.1007/s10681-008-9690-9

Zhang H, Pala M, Oweis T, Harris H (2000) Water use and water-use efficiency of chickpea and lentil in a Mediterranean environment. Aust J Agric Res 51:295-304 